\title{
The SEISMOFAULTS project: first surveys and preliminary results for the Ionian Sea area, southern Italy
}

\author{
Andrea Billi ${ }^{*}, 1$, Marco Cuffaro ${ }^{1}$, Laura Beranzoli ${ }^{2}$, Sabina Bigi ${ }^{3}$, Alessandro Bosman ${ }^{1}$, \\ Cinzia Caruso $^{4}$, Alessia Conti ${ }^{3}$, Andrea Corbo ${ }^{4}$, Antonio Costanza ${ }^{5}$, Giuseppe D'Anna ${ }^{5}$, \\ Mariagrazia De Caro ${ }^{2}$, Carlo Doglioni ${ }^{2,3}$, Davide Embriaco ${ }^{6}$, Gioacchino Fertitta ${ }^{5}$, \\ Francesco Frugoni ${ }^{2}$, Luca Gasperini ${ }^{7}$, Francesco Italiano ${ }^{4}$, Gianluca Lazzaro ${ }^{4}$, \\ Marco Ligi ${ }^{7}$, Eleonora Martorelli ${ }^{1}$, Stephen Monna ${ }^{2}$, Caterina Montuori ${ }^{2}$, \\ Alessandra Nigrelli ${ }^{4}$, Giuseppe Passafiume ${ }^{4}$, Lorenzo Petracchini ${ }^{1}$, Patrizio Petricca ${ }^{3}$, \\ Alina Polonia ${ }^{7}$, Giampaolo Proietti ${ }^{3}$, Livio Ruggiero ${ }^{3}$, Tiziana Sgroi ${ }^{2}$, Maria Chiara Tartarello ${ }^{3}$ \\ (1) Consiglio Nazionale delle Ricerche, IGAG, Rome, Italy \\ (2) Istituto Nazionale di Geofisica e Vulcanologia, Rome, Italy \\ (3) Sapienza Università di Roma, Dipartimento di Scienze della Terra, Rome, Italy \\ (4) Istituto Nazionale di Geofisica e Vulcanologia, Palermo, Italy \\ (5) Istituto Nazionale di Geofisica e Vulcanologia, Gibilmanna, Italy \\ (6) Istituto Nazionale di Geofisica e Vulcanologia, Portovenere, Italy \\ (7) Consiglio Nazionale delle Ricerche, ISMAR, Bologna, Italy
}

Article history: received March 28, 2019; accepted October 14, 2019

\begin{abstract}
The SEISMOFAULTS project (www.seismofaults.it) was set up in 2016 with the general plan of exploring the seismicity of marine areas using deep seafloor observatories. The activity of the first two years (Seismofaults 2017 and 2018) consisted of the installation of a geophysical-geochemical temporary monitoring network over the Ionian Sea floor. Eleven ocean-bottom seismometers with hydrophones (OBS/H) and two seafloor geochemical-geophysical multiparametric observatories were deployed to: (1) identify seismically active faults; (2) identify potential geochemical precursors of earthquakes; and (3) understand possible cause-effect relationships between earthquakes and submarine slides. Furthermore, five gravity cores were collected from the Ionian Sea bottom and 4082 $\mathrm{km}$ of geophysical acquisition, including multibeam and single channel seismic reflection data, were acquired for a total of $4970 \mathrm{~km}^{2}$ high-resolution multibeam bathymetry. Using Niskin bottles, four water column samples were collected: two corresponding at the location of the two multiparametric observatories (i.e., along presumably-active fault zones), one corresponding at a recently discovered mud volcano, and one located above a presumably-active fault zone away from the other three sites. Preliminary results show: (1) a significant improvement in the quality and quantity of seismological records; (2) endogenous venting from presumably active faults; (3) active geofluid venting from a recently-discovered mud volcano; and (4) the correct use of most submarine devices. Preliminary results from the SEISMOFAULTS project show and confirm the potential of multidisciplinary marine studies, particularly in geologically active areas like southern Italy and the Mediterranean Sea.
\end{abstract}

Keywords: Earthquake; Ionian Sea; OBS. 


\section{Andrea Billi et al.}

\section{Introduction}

Although the focus of scientific research is rapidly expanding towards and beyond the limits of our solar system, the surface and shallow layers of our planet, particularly the (deep) marine areas, are still largely unexplored. The marine areas often host active faults, volcanoes, and other structures that are potentially dangerous or able to have a strong impact on human life and activities [Buck et al., 2005; Smith et al., 2008; Trippetta et al., 2019].

The western Ionian Sea and its adjoining regions (Calabria and Sicily, southern Italy; Figure 1) have long been the locus of destructive seismic events [Billi et al., 2010; Polonia et al., 2012; Guidoboni et al., 2018] and associated violent tsunamis [Tinti et al., 2004] that have triggered submarine slope failures and turbidity currents [Polonia et al., 2013]. We here recall the 1908 (Mw 7.2), 1905 (Mw 7.0), 1783 (Mw 6.9), 1693 (Mw 7.4), 1169 (Mw 6.6), and 362 (Mw 6.6) $\mathrm{AD}$ earthquakes and tsunamis, which provoked devastation and death (e.g., more than 80,000 casualties in 1908).



Figure 1. Geological and tectonic setting of the Ionian Sea, southern Italy [modified from Polonia et al., 2017].

These events have been studied by many geologists and geophysicists for the great force they had; however, their cause and origin (zone and generation mechanism) is still greatly debated. For instance, it is not yet known whether the tsunamis were caused directly by the earthquake-related seabed displacement or indirectly by seismically triggered submarine landslides [Valensise and Pantosti, 1992; Billi et al., 2008, 2010; Tappin et al., 2008; Argnani et al., 2009; Favalli et al., 2009; Casalbore et al., 2012; Ridente et al., 2014; Polonia et al., 2016b; Schambach et al., 2020]. 
The lack of an adequate network of seismometers over the bottom of the Ionian Sea and of a continuous monitoring of other geophysical and geochemical data prevents a full comprehension of the tectonic, seismological, and geomorphological processes that are active in the western Ionian Sea. In recent years, however, the acquisition of multibeam and multi-channel seismic reflection data [Minelli and Faccenna, 2010; Polonia et al., 2011; Gutscher et al., 2016, 2017] and gravity cores taken from the seabed [Polonia et al., 2013], together with the observations from a permanent multiparameter station [Monna et al., 2005; Sgroi et al., 2007] have suggested a new tectonic framework of the Ionian Sea. This framework has led to significant improvements in our knowledge of the hazards [Polonia et al., 2012; Sgroi et al., 2014]. Faults that may have caused one or multiple deadly earthquakes and tsunamis have been recently recognised and mapped [Polonia et al., 2016a, 2016b, 2017; Figure 1], such as the Ionian and Alfeo-Etna fault systems (Figure 1).

In the case of the Ionian Sea, it is therefore necessary to: (1) instrumentally-observe these faults (Figure 1) and establish whether they are seismically-active; (2) understand whether the seismic activity along these structures could be predicted by possible precursory phenomena, such as geofluid venting from fault zones and/or mud volcanoes; and (3) understand whether submarine slides along the Sicilian-Calabrian margins can be caused by seismic events of low-to-intermediate magnitude.

These goals have been achieved within the multidisciplinary marine SEISMOFAULTS project (www.seismofaults.it) has been set up by Consiglio Nazionale delle Ricerche (CNR), Istituto Nazionale di Geofisica e Vulcanologia (INGV), and Sapienza University of Rome (Sapienza). The first year of the project (2017) mainly involved installing a geophysical-geochemical temporary monitoring network across the floor of the Ionian Sea (Figure 2). The instruments were recovered in May 2018 during the Seismofaults 2018 survey. On this same survey, three more ocean-bottom seismometers with hydrophones $(\mathrm{OBS} / \mathrm{H})$ were deployed to continue monitoring the seismicity of the Ionian region.

In this paper, we describe the preliminary results of the first two marine surveys of the SEISMOFAULTS project (the Seismofaults 2017 and 2018 surveys completed in May 2017 and May 2018; www.seismofaults.it). Our main objective is to highlight the potential of this type of multidisciplinary research.

\section{Geological setting}

Convergence and contraction along the Africa-Eurasia plate boundary in the Mediterranean are partly accommodated by the Calabrian Arc subduction system, where the Ionian crust and lithosphere subduct toward NW beneath the Calabrian accretionary prism and the Tyrrhenian lithosphere (Figure 1). The accretionary prism, which is partly on-shore (Calabria and Peloritani Mts.) and mostly off-shore (Ionian Sea), developed through deformation of the thick sedimentary sequence lying on the African subducting plate. In particular, shortening, was taken up both along the outer deformation front and in the inner portions of the accretionary wedge [Amodio-Morelli et al., 1976; Cernobori et al., 1996; Doglioni et al., 1999; Minelli and Faccenna, 2010; Polonia et al., 2011; Gallais et al., 2012].

Three main morpho-structural domains have been defined within the Calabrian accretionary prism in the Ionian Sea area [Polonia et al., 2011]. Moving from SE to NW, these domains are (Figure 1): (1) the frontal saltbearing post-Messinian accretionary wedge; (2) the pre-Messinian clastic accretionary wedge; and (3) the inner plateau, which is a morphologically flat domain where forearc basins have developed atop the continental basement. These domains are rheologically different and different tectonic processes affect or have affected these domains, resulting in varying topographic slope angles, basal detachment depths, and structural styles.

The post-Messinian accretionary wedge includes a thick (up to $6 \mathrm{~km}$ ) pile of evaporites. Frontal accretion presently occurs in this domain involving a basal thrust located at the bottom of the Messinian evaporites. The pre-Messinian accretionary wedge includes Tertiary and Mesozoic sediments. In this domain, the basal thrust is located at deeper levels than the frontal thrust. The transition between the flat inner plateau and the preMessinian accretionary prism is identified by compound fault zones (Figure 1) that, in places, trigger geofluid ascent and mud volcanoes activity [Praeg et al., 2009; Panieri et al., 2013; Loher et al., 2018; Cuffaro et al., 2019].

A set of linear faults and deformation zones that cuts through the Calabrian accretionary complex in the NNW-SSE, NW-SE, and WNW-ESE directions (Figure 1), represent the shallow appearance of deeply rooted 


\section{Andrea Billi et al.}

processes as testified by mantle sourced diapirs aligned along such faults [Polonia et al., 2017]. A main NWstriking deformation zone (Ionian Fault system) delimits the western and eastern lobes of the accretionary prism. This deformation zone elongates between the Messina Straits region and the Ionian abyssal plain, cutting through the entire subduction complex.

The western and eastern lobes of the Calabrian prism (WL and EL, respectively) are very different from a structural point of view. The western lobe (WL; offshore Sicily) is characterised by a very low (about $1.5^{\circ}$ ) tapered salt-bearing accretionary prism delimited towards the Italian peninsula by a slope terrace hosting a Messinian thrust-top basin. This flat region, located between the inner and outer wedges, occurs where the basal thrust involves deeper layers down to the basement with formation of out-of-sequence thrusts (splay faults) and duplexes. At the front of central Calabria, the eastern lobe (EL) shows a more elevated accretionary prism that is between 1000 and $1500 \mathrm{~m}$ shallower than in the WL. Moreover, the EL is characterized by steeper topographic slopes and higher deformation rates than the WL. Variations in the structural styles between the EL and WL coincide with differences in the depth of the basal thrust (that is about $4 \mathrm{~km}$ shallower in the WL) and with the occurrence of thrust faults affecting the basement in the EL [Polonia et al., 2011, 2012].

A set of NNW-SSE trending fault systems characterizes the WL, inducing across-strike margin segmentation [Hirn et al., 1997; Bianca et al., 1999; Nicolich et al., 2000; Argnani and Bonazzi, 2005; Chamot-Rooke et al., 2005; Del Ben et al., 2008; Rosenbaum et al., 2008; Polonia et al., 2011, 2012; Gallais et al., 2013; Scarfì et al., 2016]. The major fault in this region is an active transtensive fault elongating between the Alfeo seamount and the area offshore of the Etna volcano. This set of transtensional faults possibly re-activates Messinian-Pliocene thrust faults, causing a vertical offset of the accretionary prism. The transtensional set occurs along a preexisting Mesozoic structure and is accompanied by a basin floored by a 700-m-thick relatively-undeformed sedimentary infilling [Polonia et al., 2011, 2012, 2016a]. For its geographical location, the main NNW-SSE trending fault in the WL was named Alfeo-Etna Fault (AEF) system after Polonia et al. [2016a]. The transtensional faults, segmenting the continental margin offshore of Sicily (Figure 1), are likely the most seismically-active faults in the region [Monaco and Tortorici, 2000; Presti et al., 2013; Totaro et al., 2013; Polonia et al., 2016a; Barreca et al., 2018; Presti, 2020] and hence, they were the main target of the Seismofaults 2017 and 2018 surveys. The multidisciplinary approach of these surveys is described below.

\section{First surveys: Seismofaults 2017 and 2018}

The first cruise of the SEISMOFAULTS project, i.e. the Seismofaults 2017 scientific cruise, lasted 14 days and took place in May 2017. The main purpose of the cruise was the deployment of eight OBS/H and two multiparametric geochemical-geophysical observatories at specific locations on the Ionian seafloor, as shown in Figure 2 (Table 1). Five gravity cores were also collected from the sea bottom (Figure 2 and Table 1) and $\sim 4082 \mathrm{~km}$ of geophysical data, including high-resolution multibeam bathymetry and single channel seismic reflection profiles, were acquired in three working areas (Areas I, II, and III; Figure 2), resulting in a total of $4970 \mathrm{~km}^{2}$ highresolution multibeam bathymetry [Cuffaro et al., 2019].

Conductivity-temperature-depth (CTD) casts were performed along the seawater column to obtain temperature, conductivity, salinity, and sound velocity profiles that are necessary to calibrate the multibeam measurements. Four water column samples were collected with Niskin bottles: two at the two multiparametric observatories sites, one on a recently discovered mud volcano, and one located along a fault zone far away from the other three sites (Figure 2 and Table 1). CTD casts were also performed at the sites of water sampling.

The Seismofaults 2018 survey was completed in May 2018. During this four-day cruise, seven OBS/H (version B) were recovered following connection routes reported in Figure 2. At sites corresponding to OBS/H B7, OBS/H $\mathrm{B} 9$, and $\mathrm{OBS} / \mathrm{H} \mathrm{B} 4$, three additional OBS/H (version $\mathrm{A}$ ) were deployed during the same cruise $(\mathrm{OBS} / \mathrm{H} \mathrm{A6}, \mathrm{OBS} / \mathrm{H}$ $\mathrm{A} 2$, and $\mathrm{OBSH} / \mathrm{A} 5$ ). During OBSs' recovering, OBS/H B4 sent a release signal from the seafloor, but never arrived at the sea surface, probably due to an obstacle that stopped the ascent. The two multiparametric observatories were recovered during a previous cruise in the Ionian Sea in April 2018. The locations of the three OBS/H (version A) deployed in May 2018 are reported in Figure 2 and Table 1. These three OBS/H were safely recovered in April 2019 during the Seismofaults 2019 survey. 
The SEISMOFAULTS project in Ionian Sea



Figure 2. Workplan of the Seismofaults 2017 and 2018 scientific cruises in the Ionian Sea (Table 1). Red crosses are the deployment locations of eleven seafloor seismometers (three OBS/H version A deployed in 2018 and eight OBS/H version B deployed in 2017). Open circles are the deployment locations of two seafloor multiparametric geochemical-geophysical observatories. Yellow crosses are locations of five gravity cores. Samples for the seawater column analyses were collected above the GeoC1, GeoC2, and GeoC3 sites, and above the location of Core SF17_01. Solid boxes correspond to location of the geophysical acquisition working areas, whereas the dashed box is the calibration patch test area (Figure 3). Black dashed lines are the multibeam navigation track lines of the oceanographic cruises.

\begin{tabular}{|c|c|c|c|c|c|}
\hline Day & Time & Name & Longitude $\left({ }^{\circ} \mathbf{E}\right)$ & Latitude $\left({ }^{\circ} \mathrm{N}\right)$ & Depth (m) \\
\hline \multicolumn{6}{|c|}{ seismometers OBS/H } \\
\hline May $10^{\text {th }}, 2017$ & 19.45 & OBS/H B6 & $16^{\circ} 02.83^{\prime}$ & $37^{\circ} 45.77^{\prime}$ & 1583 \\
\hline May $10^{\text {th }}, 2017$ & 05.25 & OBS/H B7 & $16^{\circ} 22.49^{\prime}$ & $37^{\circ} 41.37^{\prime}$ & 2065 \\
\hline May $10^{\text {th }}, 2017$ & 08.51 & OBS/H B8 & $16^{\circ} 31.78^{\prime}$ & $37^{\circ} 25.91^{\prime}$ & 2671 \\
\hline May $10^{\text {th }}, 2017$ & 12.22 & OBS/H B9 & $16^{\circ} 07.10^{\prime}$ & $37^{\circ} 12.37^{\prime}$ & 2752 \\
\hline May $10^{\text {th }}, 2017$ & 15.38 & OBS/H B4 & $15^{\circ} 38.79^{\prime}$ & $37^{\circ} 00.47^{\prime}$ & 2330 \\
\hline May $10^{\text {th }}, 2017$ & 17.27 & OBS/H B3 & $15^{\circ} 30.35^{\prime}$ & $37^{\circ} 14.28^{\prime}$ & 2256 \\
\hline May $10^{\text {th }}, 2017$ & 19.19 & OBS/H B5 & $15^{\circ} 42.39^{\prime}$ & $37^{\circ} 24.55^{\prime}$ & 2242 \\
\hline May $11^{\text {th }}, 2017$ & 08.56 & OBS/H B2 & $15^{\circ} 27.33^{\prime}$ & $37^{\circ} 42.22^{\prime}$ & 1767 \\
\hline May $16^{\text {th }}, 2018$ & 02.24 & OBS/H A6 & $16^{\circ} 22.44^{\prime}$ & $37^{\circ} 41.37^{\prime}$ & 2065 \\
\hline May $16^{\text {th }}, 2018$ & 10.26 & OBS/H A2 & $16^{\circ} 07.09^{\prime}$ & $37^{\circ} 12.40^{\prime}$ & 2752 \\
\hline May $16^{\text {th }}, 2018$ & 15.51 & OBS/H A5 & $15^{\circ} 38.71^{\prime}$ & $37^{\circ} 00.58^{\prime}$ & 2330 \\
\hline
\end{tabular}




\begin{tabular}{|c|c|c|c|c|c|}
\hline Day & Time & Name & Longitude $\left({ }^{\circ} \mathrm{E}\right)$ & Latitude $\left({ }^{\circ} \mathrm{N}\right)$ & Depth (m) \\
\hline \multicolumn{6}{|c|}{ multiparametric geochemical-geophysical observatories } \\
\hline May $17^{\text {th }}, 2017$ & 06.39 & Geo_C2 & $15^{\circ} 26.70^{\prime}$ & $37^{\circ} 43.22^{\prime}$ & 1680 \\
\hline May $17^{\text {th }}, 2017$ & 16.53 & Geo_C1 & $15^{\circ} 28.50^{\prime}$ & $37^{\circ} 57.46^{\prime}$ & 1088 \\
\hline \multicolumn{6}{|c|}{ gravity cores } \\
\hline May $17^{\text {th }}, 2017$ & 10.10 & SF17_01 & $16^{\circ} 16.84^{\prime}$ & $37^{\circ} 52.65^{\prime}$ & 1348 \\
\hline May $17^{\text {th }}, 2017$ & 18.42 & SF17_02 & $15^{\circ} 31.72^{\prime}$ & $37^{\circ} 43.04^{\prime}$ & 1633 \\
\hline May $18^{\text {th }}, 2017$ & 08.15 & SF17_03 & $15^{\circ} 49.31^{\prime}$ & $37^{\circ} 09.87^{\prime}$ & 2496 \\
\hline May $18^{\text {th }}, 2017$ & 12.00 & SF17_04 & $15^{\circ} 47.89^{\prime}$ & $37^{\circ} 09.15^{\prime}$ & 2418 \\
\hline May $18^{\text {th }}, 2017$ & 14.57 & SF17_05 & $15^{\circ} 55.59^{\prime}$ & $37^{\circ} 22.55^{\prime}$ & 2370 \\
\hline \multicolumn{6}{|c|}{ seawater column sampling } \\
\hline May $16^{\text {th }}, 2017$ & 11.58 & Geo_C3-Niskin_01 & $15^{\circ} 23.03^{\prime}$ & $37^{\circ} 28.18^{\prime}$ & 2062 \\
\hline May $16^{\text {th }}, 2017$ & 18.00 & Geo_C2-Niskin_02 & $15^{\circ} 26.68^{\prime}$ & $37^{\circ} 48.18^{\prime}$ & 2000 \\
\hline May $17^{\text {th }}, 2017$ & 10.25 & Geo_C1-Niskin_03 & $15^{\circ} 28.50^{\prime}$ & $37^{\circ} 57.42^{\prime}$ & 900 \\
\hline May $17^{\text {th }}, 2017$ & 08.10 & CTD_x-Niskin_04 & $16^{\circ} 16.84^{\prime}$ & $37^{\circ} 52.65^{\prime}$ & 1348 \\
\hline
\end{tabular}

Table 1. List of sites for instrument deployment (OBS/H and multiparametric observatories) and sampling (gravity cores and seawater columns) during the Seismofaults 2017 and 2018 surveys.

\section{Methods}

\subsection{High-resolution multibeam bathymetry}

High-resolution bathymetric surveys (Seismofaults 2017) were carried out using a multibeam Teledyne Reson SeaBat 7160 (41-47 kHz) echosounder with a footprint size of $1^{\circ} \times 1^{\circ}$. Positioning was obtained by a differential GNSS system (accuracy $\pm 0.5 \mathrm{~m}$ ), while sound velocity profiles were estimated from multiple CTD casts (Seabird 911plus) to ray trace the acoustic wave along the water column. Multibeam data were processed onboard using Caris Hips \& Sips (H\&S) hydrographic software with the following parameters and processing methods: (a) corrections for tidal height variations from the Catania harbour tide gauge (www.mareografico.it); (b) multibeam calibration (patch test) to measure the angular misalignment between the transducers, motion sensor, gyro, and position latency; (c) statistical and geometric (angle and distance) filters to remove coherent and incoherent noise in each swath; (d) manual removal of isolated fake soundings; and (e) generation of a high-resolution digital elevation model with a grid resolution varying from $10 \mathrm{~m}$ in deep water (down to $-1000 \mathrm{~m}$ water depth) to $25 \mathrm{~m}$ at greater depths [Bosman et al, 2015].

To calibrate multibeam data, a patch test area was selected at a water depth of $1600 \mathrm{~m}$ (dashed box, Figure 2) close to a morphological high and a sub-linear sector (Figure 3). The multibeam patch test conducted with PDS2000 and verified with Caris $\mathrm{H} \& \mathrm{~S}$ provided the following values: time delay $=0.0$; heading correction $=-0.930^{\circ}$; roll correction $=0.680^{\circ}$; pitch correction $=-1.020^{\circ}$; and time delay $=0.00 \mathrm{sec}$.

\subsection{Single-channel seismic profiles}

High resolution seismic stratigraphy is based on chirp seismic profiles. These profiles were acquired using a frequency-modulated source (Seismofaults 2017) operating in the frequency range of 2-7 kHz (Benthos Chirp III) and 
The SEISMOFAULTS project in Ionian Sea
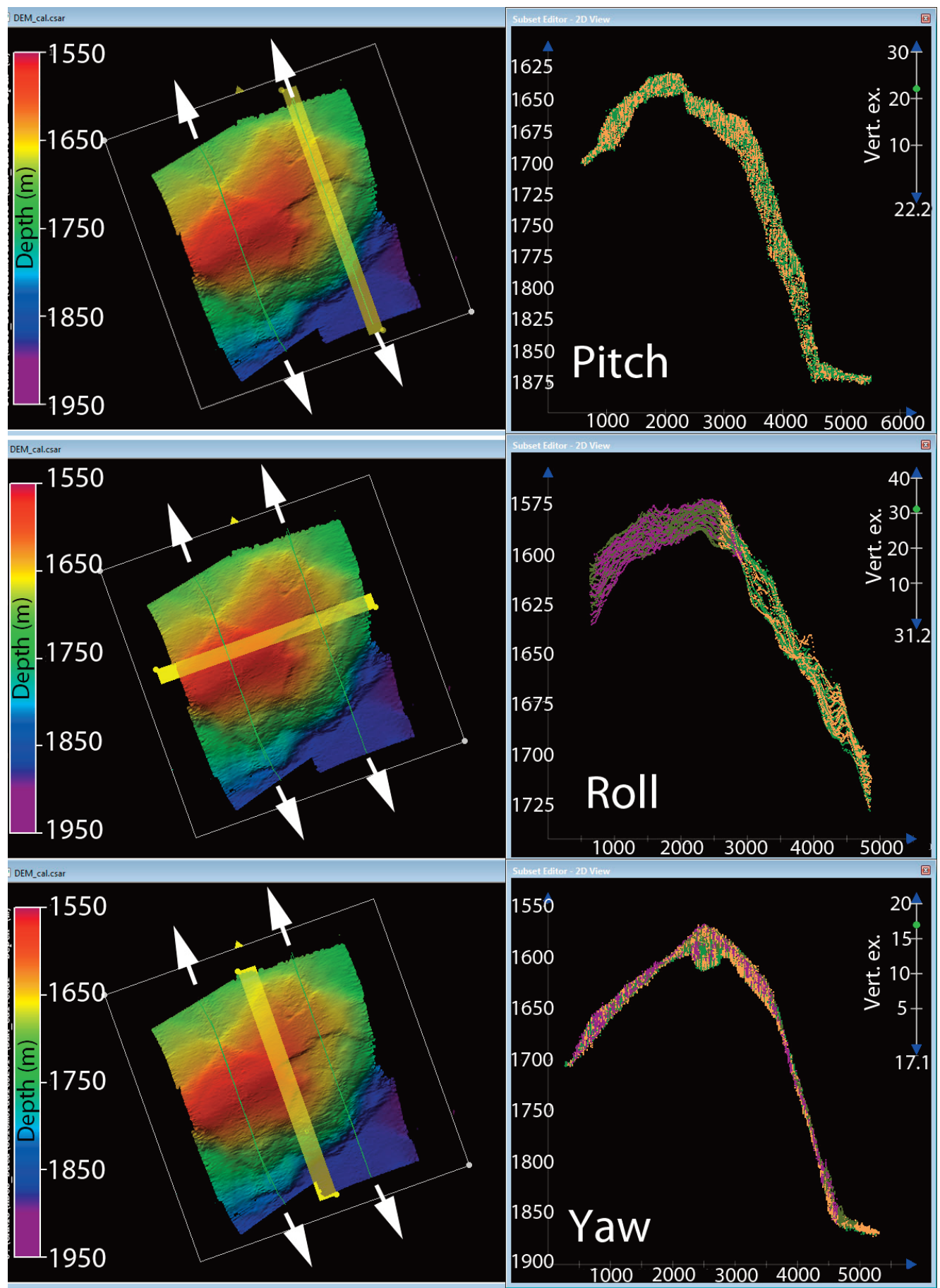

Figure 3. Multibeam calibration patch test. Calibration results and $10 \mathrm{~m}$ resolution DEM generated using the four lines acquired in the calibration patch test area displayed in Figure 2. Selected swath corridors along calibration lines are shown on the left panels overimposed to DEM, whereas swath soundings are displayed on the right panels. Multibeam calibration, conducted with PDS2000 and verified with Caris H\&S provided the following offset parameters: Time delay: 0.0 ; Heading correction: $-0.930^{\circ}$; Roll correction: $0.680^{\circ}$; Pitch correction: $-1.020^{\circ}$; and time delay: $0.00 \mathrm{sec}$.

recorded with a $0.5-0.8 \mathrm{~s}$ sweep length. Maximum sub-bottom penetration was up to about $20 \mathrm{~m}$ and vertical resolution was about $0.5-0.75 \mathrm{~m}$. The Chirp lines were processed using the GeoSuite All Works software applying a time-variant gain. Thicknesses and depths of seismic sequences and reflectors are described in two-way travel time (TWT), with a seismic velocity of $1500 \mathrm{~m} / \mathrm{s}$ to convert two-way travel time into depth. Seismic data interpretation was carried out using the Kingdom Suite software and integrated with the bathymetric data. 


\section{Andrea Billi et al.}

\subsection{BB - OBS/H (broad-band ocean bottom seismometer with hydrophone)}

During Seismofaults 2017, eight INGV broad-band OBS/H (version B) were used. These new devices were released in 2017, nine years after the release of the previous version (i.e. INGV broad band OBS/H version A). This new design (Figure 4) comes from the experience gained while working with the seven former OBS/H [e.g. D’Alessandro et al., 2009; Coltelli et al., 2016]. Other experiences in deep sea with broad-band OBS/H are reported, for example in Barberi et al. [2006], Kasahara et al. [2006], Sgroi et al. [2006], D’Alessandro et al. [2012], Giovanetti et al. [2016], and Ibáñez et al. [2016a, 2016b]. OBS/H version B was the result of several important changes applied to version A to simplify operational procedures and better assure data quality. Deep-sea-rated syntactic foam blocks are now used to provide the required buoyancy and titanium grade 5 for the frame and vessel that hold the instrument and batteries. These top-quality materials have become essential in undersea deep operations. Furthermore, the OBS/H (version B) can now be equipped with a broad-band seismometer plus a hydrophone or a differential pressure gauge (DPG).


Figure 4. Lateral (left) and 3D view (top right) of seabottom seismometers (OBS/H version B) deployed during the Seismofaults 2017 survey. The devices are designed and partly assembled by the INGV OBS Lab in Gibilmanna. Photograph (bottom right) taken on the deck of the Minerva Uno scientific vessel during the Seismofaults 2017 survey. 
During the Seismofaults 2017 survey, the deepest OBS/H station was at a depth of c. $2800 \mathrm{~m}$. In the deployment, the seismometer must be anchored as firmly as possible to the seabed to produce meaningful waveforms. Furthermore, it must be shielded against marine currents and other noise sources. This new OBS/H has a special architecture that combines the burn-wire method for best coupling to the seabed with a telescopic shield for maximum protection against currents.

The OBS/H (version B) is designed, assembled, and fully tested by the INGV OBS Lab in Gibilmanna, Sicily, southern Italy. Positioning devices include: (1) a XENON flash beacon for night-time recovery; (2) a VHF radio beacon, which makes the OBS detectable through a radiogoniometer; and (3) an IRIDIUM satellite beacon with integrated GPS receiver. An IXBLUE acoustic release customised at the INGV OBS Lab in Gibilmanna drives the burn-wire system. The OBS/H (version B) can be optionally equipped with other instruments, such as pressure sensors for tsunami detection or a CTD sensor, provided that the added weight is less than $10 \mathrm{~kg}$. Mission time is up to 15 months. Table 2 shows all specifications of the OBS/H (version B).

Main features of seismometers OBS/H (Version B)

Frame

Electronic canister

\begin{tabular}{cc}
\hline Buoyancy & Syntactic $6000 \mathrm{~m}$ \\
\hline Release & IXBLUE AR861 RM INGV customized \\
\hline Release type & Burn-wire \\
\hline Digitizer & Guralp CD24
\end{tabular}

\begin{tabular}{cc}
\hline Seismic sensor & Trillium OBS Nanometrics 120 sec-100Hz \\
\hline Hydrophone & HTI-04PCA/ULF + INGV preamplifier \\
\hline Differential Pressure Gauge & Cox -Webb + INGV preamplifier \\
\hline Positioning devices & Xenon Flash + VHF Radio + Iridium beacons \\
\hline Extra payload & $10 \mathrm{~kg}$ \\
\hline Weight & $470 \mathrm{~kg}$ in air \\
\hline Dimensions & $100 \times 870 \mathrm{~kg}$ in water \\
\hline Operative depth & Full depth $6000 \mathrm{~m}$ \\
\hline
\end{tabular}

Table 2. List of main features for seafloor seismometers OBS/H (Version B).

During the Seismofaults 2018 survey, three INGV broad-band OBS/H (version A) were deployed on the Ionian seabed. The main parameters and characteristics of these devices have been reported in previous works [D’Alessandro et al., 2009; Coltelli et al., 2016]. For the SEISMOFAULTS project, the three OBS/H (version A) underwent a partial redesign to increase the quality of the acquired seismic signals.

Data processing is presently ongoing on the eight OBS/H deployed during Seismofaults 2017 and recovered in May 2018 (Seismofaults 2018) and on the three OBS/H deployed during Seismofaults 2018 and recovered in April 2019 (Seismofaults 2019). To highlight the potential of the OBS/H, below, we briefly present preliminary results from the Seismofaults 2017 and 2018 surveys together with results from previous similar experiences, specifically from the TYDE and SN1 projects [Dahm et al., 2002; Sgroi et al., 2006; 2007; Favali et al., 2013]. 


\section{Andrea Billi et al.}

\subsection{Multiparametric observatories}

We used two new 'stand-alone' multidisciplinary seafloor observatories developed in the mainframe of the scientific and technological activities of the EMSO - ERIC (European Multidisciplinary Seafloor and water-column Observatory, European Research Infrastructure Consortium http://emso.eu/). Photographs and the construction scheme of the multiparametric observatories are shown in Figure 5, with the main parameters and characteristics being reported in Table 3 . The multiparametric observatories are built to operate in extreme submarine environments down to a depth of $4000 \mathrm{~m}$.


Figure 5. Technical scheme (left) and three photographs (right) of multiparametric geochemical-geophysical observatories deployed during the Seismofaults 2017 survey.

In recent times, innovations in technology have increased the maximum number of synchronous acquisitions, data rates and resolution, and allowed for autonomous remote data synchronisation and reduced power consumption. In May 2017, two observatories were deployed at depths of $1088 \mathrm{~m}$ and $1689 \mathrm{~m}$ in the Ionian Sea off the eastern coast of Sicily during the Seismofaults 2017 cruise (Figure 2, Table 1). The multidisciplinary observatories collected acoustic signals (Reson TC4037 hydrophone), as well as data regarding the dissolved oxygen, temperature, pressure, $\mathrm{pH}, \mathrm{EC}$, and turbidity. The planned monitoring period was 12 months. The aim of the experiment was to understand whether the tectonic structures identified on the seafloor (mud volcanoes or faults) host degassing processes and whether this fluid venting activity changes with time in relation to earthquakes and fault movements. 
To achieve this goal, the observatories were deployed along previously identified active tectonic structures [Argnani and Bonazzi, 2005; Argnani et al., 2009; Polonia et al., 2012, 2016a; Gutscher et al., 2015, 2017] (Figure 2).

Multiparametric observatories

\begin{tabular}{|c|c|}
\hline Dimensions $(\mathrm{cm})$ & $120 \times 120 \times 180(h)$ \\
\hline Weight in air & $290 \mathrm{~kg}$ \\
\hline Weight in salt water & $85 \mathrm{~kg}$ \\
\hline Ballast & $\begin{array}{l}\text { Weight: } 1000 \mathrm{~kg} \text { in air and } 540 \mathrm{~kg} \text { in salt water; Nylon frame, hard anodized } \\
\text { aluminum vessels containing batteries and datalogger }\end{array}$ \\
\hline Sensors on board & $\begin{array}{c}\text { Sea-Bird Temperature, Pressure, pH, electric conductivity (salinity), turbidity, } \\
\text { HTI Hydrophone }\end{array}$ \\
\hline Buoyancy benthos spheres & $17 ”, 22 \mathrm{~kg}$ \\
\hline Temperature sensor & SBE 3 Plus, Max depth $6800 \mathrm{~m}$ \\
\hline Pressure + Temperature sensor & SBE 29, Max depth $6800 \mathrm{~m}$ \\
\hline Turbidimetry sensor & STM 11 \\
\hline pH sensor & SBE18, Max depth $1200 \mathrm{~m}$ \\
\hline Electric Conductivity EC sensor & SBE 04C, Max depth $6800 \mathrm{~m}$ \\
\hline Submersible Pump & SBE 5T, Max depth $10500 \mathrm{~m}$ \\
\hline Hydrophone & HTI 94-SSQ-PA-004 with pre-amplifier \\
\hline Acoustic release & IX Blue Oceano 2500 \\
\hline
\end{tabular}

Table 3. The multiparametric observatories are built to operate in extreme submarine environments up to $4000 \mathrm{~m}$ in depth.

\subsection{Seawater column geochemistry}

Three vertical casts by Rosette and Niskin bottles were carried out near the deployment area of the two multiparametric observatories (deployed at depths of $1088 \mathrm{~m}$ and $1689 \mathrm{~m}$; Figure 2 and Table 1). Samples were compared with the local air-saturated seawater (ASSW). Vials were filled with $120 \mathrm{ml}$ of sea water collected at different depths and crimped to avoid air contamination. Chemical analyses were done on the gas phase obtained after the attainment of the equilibrium (at constant temperature) between the water sample and a known volume of host high-purity gas (argon) injected into the bottle used for sampling [see Sugisaki and Taki, 1987 and Capasso and Inguaggiato, 1998 for details].

The analytical determinations were done by an Agylent 7800B gas chromatograph characterized by a double detector (TCD-FID) using argon as carrier gas. Helium isotope analyses were done on the gas fractions obtained by using the same procedure described above for the gas chromatography. Next, following the procedures proposed by Sano and Wakita [1988], the sample was purified. Water samples of $100 \mathrm{ml}$ were stored in PVC bottles for total alkalinity titration. A volume of $50 \mathrm{ml}$ for each sample was filtered by a $0.45 \mu \mathrm{m}$ filter and acidified by $\mathrm{HNO}_{3} 0.1 \mathrm{~N}$ for cations ( $\mathrm{Ca}, \mathrm{Mg}, \mathrm{Na}$, and $\mathrm{K}$ ) determination, whereas the non-acidified samples were collected for anions $\left(\mathrm{Cl}, \mathrm{F}\right.$, and $\left.\mathrm{SO}_{4}\right)$ determination. $\mathrm{pH}$ and $\mathrm{EC}$ were measured by electronic instruments calibrated in situ using buffer solutions.

Chemical analyses of the major constituents were done in the laboratory on filtered $(0.45 \mathrm{~mm})$ and acidified $\left(100 \mathrm{~mL} \mathrm{HNO}_{3}\right.$ Suprapur) water samples ( $\mathrm{Na}, \mathrm{K}, \mathrm{Mg}$ and $\mathrm{Ca}$ ) and on untreated samples $\left(\mathrm{F}, \mathrm{Cl}, \mathrm{Br}^{-\mathrm{NO}_{3}}\right.$, and $\mathrm{SO}_{4}$ ) using ion-chromatography (Dionex ICS-1100). The $\mathrm{HCO}_{3}$ content was measured by standard titration procedures using hydrochloric acid. 


\section{Andrea Billi et al.}

\section{Preliminary results}

\subsection{Rationale}

In the following sections, we briefly report some preliminary results from the Seismofaults 2017 and 2018 surveys to verify some of our hypotheses and to explore the potentialities of the scientific approach followed in the SEISMOFAULTS project.-

\subsection{High-resolution multibeam bathymetry and single-channel seismic profiles}

The study area is located between the southern sector of the Calabrian margin and the eastern side of the Sicily escarpment (Figs. 1 and 2). The Calabrian and Sicilian margins are dominated by the substantial absence of a continental shelf and by very steep continental slopes. The latter features have a complex morphology due to the interaction between tectonically controlled scarps and several mass-wasting features, including landslide scars, canyons, and gullies. At the foot of the continental slope, the canyons lose morphological expression and depositional processes dominate. In this sector, the main features are small morphological highs and basins that confer a complex morphology (Figs. 1 and 2).

Along the Calabrian continental slope, at 9 NM from the coast and at a depth of $1350 \mathrm{~m}$, a morphological high with subcircular morphology, a diameter of $1 \mathrm{~km}$, and a lowered and truncated summit is detected in a flat area of the Ionian seabed (Figure 6). This morphological high is bordered by several ridges that are elongated parallel to the continental slope. The high is characterised by well-defined boundaries, with an elevation of $20 \mathrm{~m}$ from the surrounding seabed and an inclination of flanks of $10^{\circ}-15^{\circ}$.

In the same area, at a distance of $\sim 1 \mathrm{~km}$ toward south, a smaller circular depression can be observed. This feature displays a diameter of $320 \mathrm{~m}$ and a depth of $17 \mathrm{~m}$ from the surrounding seabed. A single-channel seismic reflection profile at the base of the main morphological high (i.e. the first one described above; Figure 6) shows a "reflection free" style in the seismic facies. Partially deformed parallel reflections can be detected in proximity of the morphological high itself (Figure 6). Geological settings and morphological characters of the described features suggest that these structures can be correlated with the emission of high-pressure fluids [e.g. Ceramicola et al., 2014]. Hence, they can be interpreted as a mud volcano [as indicated by Gutscher et al., 2017, Loher et al., 2018, and Cuffaro et al., 2019] and a pockmark, respectively.

\subsection{OBS/H: Results from previous experiments and an example from the SEISMOFAULTS dataset}

A permanent seafloor observatory has been deployed in the Ionian Sea off-shore Catania to better identify active seismogenic structures (Submarine Network 1 - SN1) [Favali and Beranzoli, 2006; Favali et al., 2006]. In the Southern Tyrrhenian Sea, the TYDE (TYrrhenian Deep sea Experiment - TYDE) [Dahm et al., 2002] involved the temporary deployment of several OBS/H modules. The data recorded by these marine seismic stations helped to improve the location accuracy of offshore earthquakes and the identification of active tectonic structures [Sgroi et al., 2006; 2007]. The same data were also used to compute 1D and 3D seismic velocity models [Monna and Dahm, 2009; Monna et al., 2013] and to evaluate the activity of seamounts and emerged volcanoes, such as Stromboli and Etna [Sgroi et al., 2009; 2014; Beranzoli et al., 2015] (Figs. 7 and 8).

During the TYDE experiment, 14 OBS/H (blue triangles in Figure 7) were deployed in the southern Tyrrhenian Sea between December 2000 and May 2001. The marine stations consisted of a wideband hydrophone (OBH) and six of them were also equipped with a $3 \mathrm{C}$ broadband seismometer (OBS; $50 \mathrm{~Hz}$ sampling rate). The marine network recorded local events (380) occurring onshore and offshore of Sicily. About 130 earthquakes were recorded by the $\mathrm{OBS} / \mathrm{H}$ and inland seismic stations.

Sgroi et al. [2006] combined the arrival times from the OBS/H and inland stations to improve the accuracy of earthquake locations in terms of rms residuals, azimuthal gaps, and epicentral and hypocentral errors. In this work, 103 local earthquakes were relocated integrating the travel times from OBS and land stations. The comparison of locations performed using the integrated network of OBS and land stations (OLS) and with land stations only (LS) 


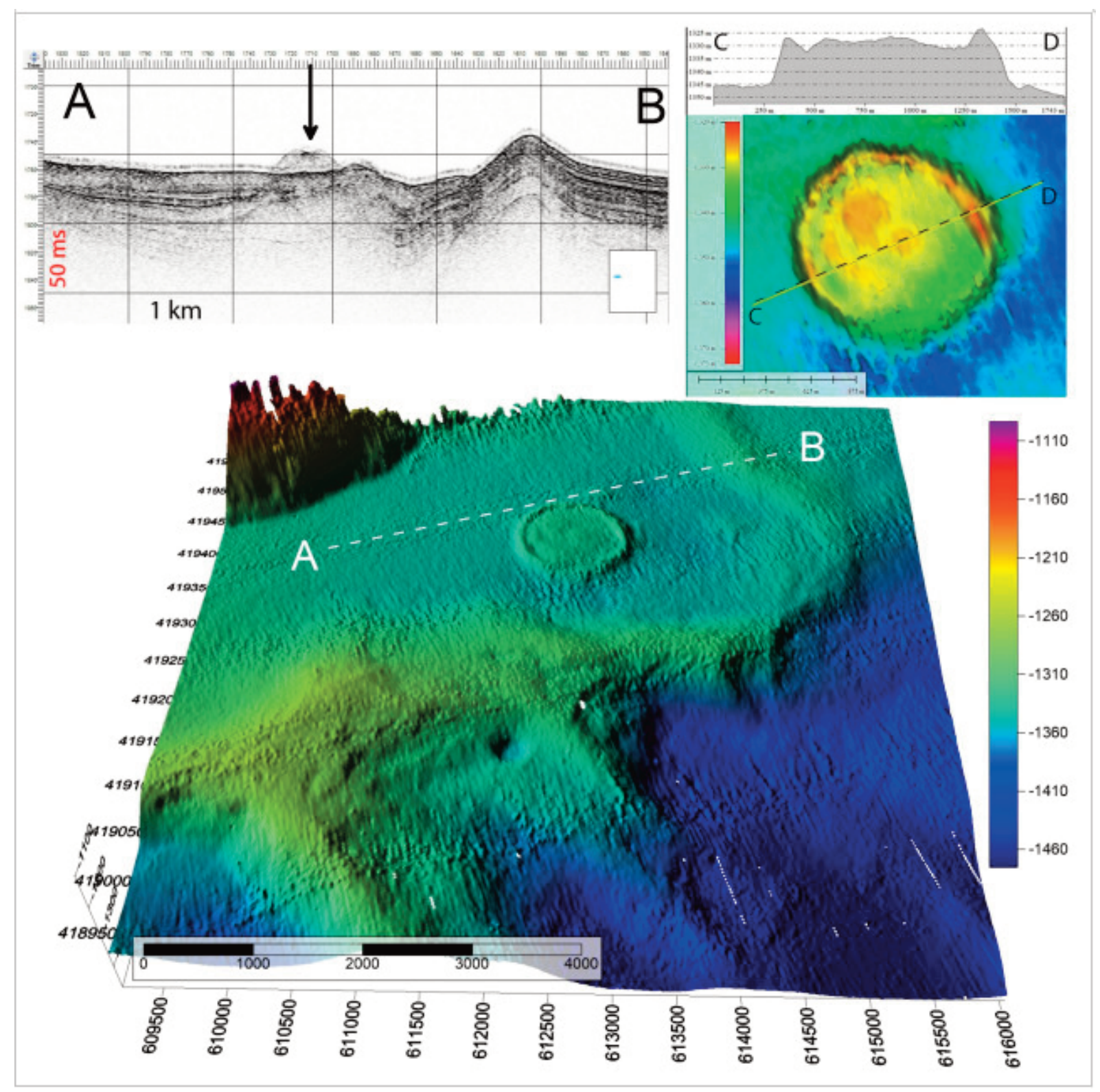

Figure 6. (Bottom and top right high resolution multibeam bathymetry data) At a distance of $9 \mathrm{~nm}$ off the southern Calabrian coast and at a depth of c. $1350 \mathrm{~m}$, a subcircular morphological feature with a diameter of c. $1 \mathrm{~km}$ and a lowered and truncated top is detected in the newly-acquired bathymetry during the Seismofaults 2017 survey. (Top left seismic reflection image). The Chirp single channel seismic reflection profile $\mathrm{AB}$ running close to the base of this feature shows a "reflection free" style of the seismic facies (black arrow), whereas partiallydeformed parallel reflections can be detected in proximity of the morphological high.

shows a reduction in terms of azimuthal gaps, rms residuals, and epicentral and hypocentral errors. The comparison between locations performed with OLS and locations performed only with LS, in terms of mean (M) computed on azimuthal gap, rms, horizontal and vertical errors highlights the high quality of locations with OLS. Differences in the azimuthal GAP up to value of $260^{\circ}$ are computed ( $M=137$ for OLS; $M=176$ for LS). While M computed on rms residuals show similar values for OLS and $\mathrm{LS}$ ( $\mathrm{M}=0.376$ and $\mathrm{M}=0.372$, respectively), there is a significant decrease of $\mathrm{M}$ computed on horizontal errors (from $\mathrm{M}=2.25$ computed on LS to $\mathrm{M}=0.49$ computed on OLS) and vertical errors (from $\mathrm{M}=3.26$ computed on LS to $\mathrm{M}=0.75$ computed on OLS). 




Figure 7. Some results from the Tyrrhenian Deep-sea Experiment (TYDE). This experiment involved the installation of 14 wide-band OBS/H (blue triangles in the top left map) in the December 2000-May 2001 period. The permanent inland stations are shown with red triangles. Many (378) earthquakes were recorded by the TYDE network in the Southern Tyrrhenian Sea during the experiment (see earthquake epicenters in black in the top left map). These events mainly occurred at crustal depths and are clustered in correspondence of the Sisifo-Alicudi and Tindari-Letojanni fault systems (see earthquake hypocenters in the cross-sectional transects in the top right and bottom images).

The OBS/H modules also recorded 275 "new" low-magnitude events (not recorded by LS) with a minimum of seven P- and S-phase arrival times that were located thanks to the OBS network.

Figure 7 shows the epicentral map and two cross-sections, including a total of 378 earthquakes in the Southern Tyrrhenian Sea located with the use of data from the TYDE experiment. Most earthquakes occur in the western Aeolian sector, clustering at crustal depths that correspond with the WNW-ESE striking Sisifo-Alicudi 


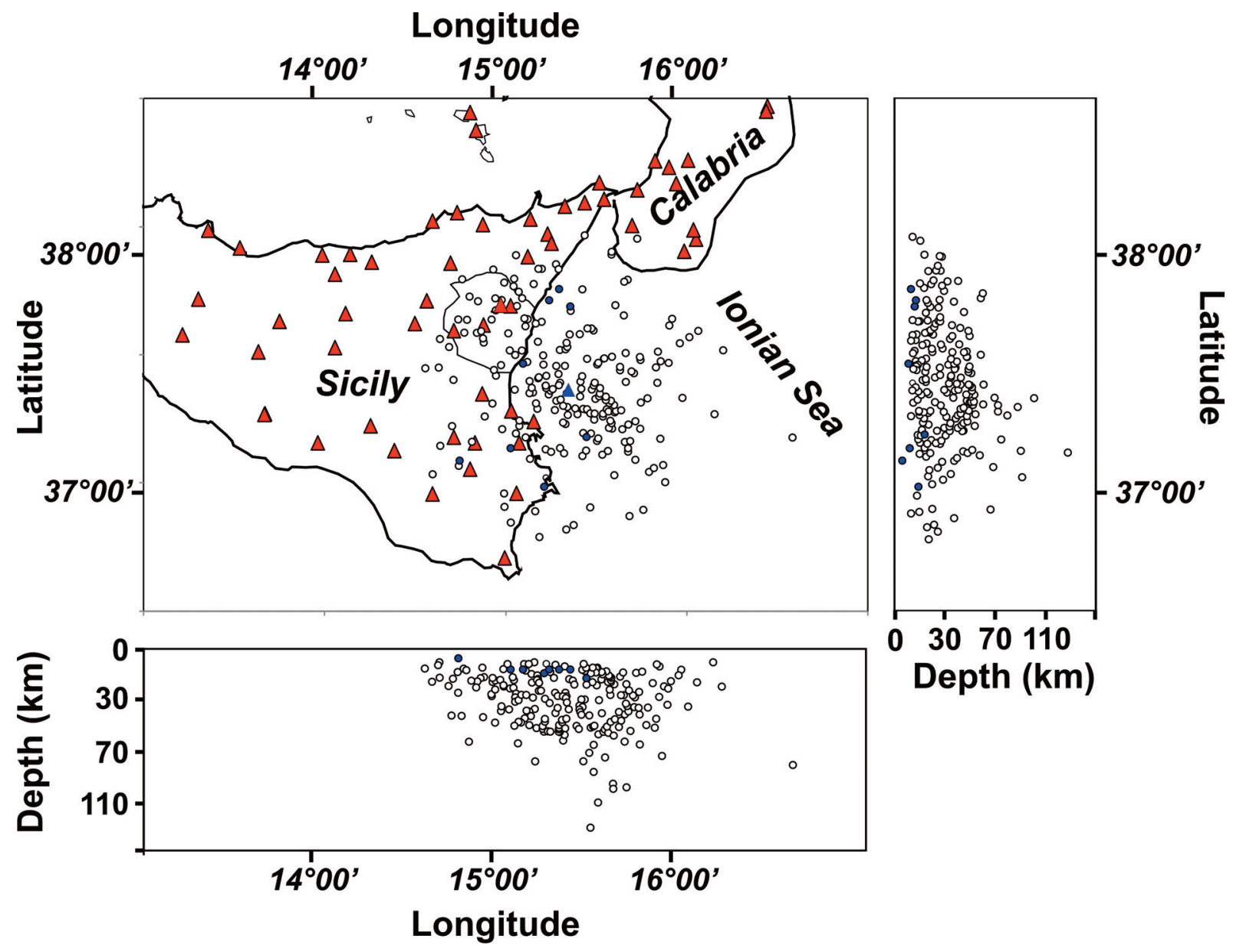

Figure 8. Location of the SN1 Seafloor Observatory (blue triangle in the top left map) between October 2002 and February 2003. The inland permanent seismic stations are shown with red triangles. Many (221) earthquakes were recorded by SN1 (see earthquake epicenters in black and blue in the top left map). The blue filled circles are a few earthquake locations from the integration of SN1 and inland data, whereas the black circles are the estimated hypocenters of earthquakes recorded by SN1. Earthquake hypocenters are shown in the cross-sectional transects in the top right and bottom images. This seismicity is linked to: (1) the external Calabrian Arc accretionary prism; (2) the tectonic structures related to the Malta Escarpment, and (3) the seismogenic structures of the deep Ionian Basin.

Fault system (Figure 1). A diffuse seismicity is concentrated in correspondence with the Tindari-Letojanni Fault (i.e. the north-westward prolongation of the Ionian Fault system; Figure 1), where some events are also clustered at subcrustal depths. 


\section{Andrea Billi et al.}

During a pilot experiment in the Ionian Sea, from October 2002 to May 2003, the SN1 seafloor observatory was deployed about $25 \mathrm{~km}$ off Catania. The seafloor observatory was equipped with geophysical instruments, including a 3C broadband seismometer (Guralp CMG-1T, 0.0027 to $50 \mathrm{~Hz}$ bandwidth, $100 \mathrm{~Hz}$ sampling rate). Here, we summarise some of the results obtained by Sgroi et al. [2007], who analysed the crustal and subcrustal seismicity recorded by the seismometer hosted within the SN1. Figure 8 shows the single-station location of earthquakes recorded by the SN1 (blue triangles).

Eight events were recorded by the SN1 and inland stations and were located using the integration of travel times (Table 4).

Locations with only land stations

Integrated locations (SN1+ISN arrival times)

Date

Orig. time Lat (N) Long (E) Depth GAP rms $\quad$ ErH $\quad$ ErZ Lat (N) Long(E) Depth GAP rms $\quad$ ErH ErZ

\begin{tabular}{ccccccccccccccc}
\hline $\begin{array}{c}02 / 10 / 14 \\
13: 17\end{array}$ & 37.130 & 14.731 & 15.56 & 179 & 0.12 & 0.6 & 1.0 & 37.124 & 14.794 & 2.97 & 127 & 0.26 & 0.3 & 0.4 \\
\hline $\begin{array}{c}02 / 10 / 16 \\
21: 42\end{array}$ & 37.191 & 15.104 & 18.88 & 113 & 0.11 & 1.1 & 1.5 & 37.157 & 15.090 & 8.30 & 110 & 0.23 & 0.5 & 0.8 \\
\hline $\begin{array}{c}02 / 11 / 28 \\
00: 00\end{array}$ & 37.206 & 15.558 & 20.53 & 267 & 0.22 & 0.7 & 1.9 & 37.203 & 15.550 & 21.04 & 266 & 0.26 & 0.6 & 0.8 \\
\hline $\begin{array}{c}02 / 12 / 04 \\
05: 17\end{array}$ & 37.647 & 15.126 & 4.22 & 109 & 0.30 & 0.5 & 0.7 & 37.667 & 15.071 & 8.11 & 100 & 0.42 & 0.3 & 0.4 \\
\hline $\begin{array}{c}02 / 12 / 17 \\
20: 12\end{array}$ & 37.029 & 15.315 & 26.66 & 287 & 0.09 & 1.0 & 0.6 & 37.004 & 15.240 & 12.79 & 248 & 0.37 & 0.6 & 0.5 \\
\hline $\begin{array}{c}03 / 01 / 05 \\
15: 53\end{array}$ & 37.778 & 15.392 & 10.42 & 134 & 0.39 & 0.3 & 0.5 & 37.782 & 15.389 & 10.54 & 118 & 0.38 & 0.3 & 0.5 \\
\hline $\begin{array}{c}03 / 01 / 05 \\
16: 46\end{array}$ & 37.811 & 15.360 & 10.87 & 149 & 0.21 & 0.9 & 1.0 & 37.843 & 15.333 & 12.36 & 113 & 0.30 & 0.7 & 0.7 \\
\hline $\begin{array}{c}03 / 02 / 12 \\
08: 57\end{array}$ & 37.869 & 15.362 & 10.01 & 119 & 0.28 & 0.3 & 0.3 & 37.875 & 15.357 & 9.99 & 106 & 0.29 & 0.2 & 0.3 \\
\hline
\end{tabular}

Table 4. Comparison [modified from Sgroi et al., 2007] between locations using only the data of the land-based network and integrated ones obtained including the SN1 arrival times. Hypocentral coordinates, gap, rms, horizontal and vertical errors are reported for both locations.

These travel times were used to compute an apparent mean velocity value used in the inversion of P- and Sarrival times versus the hypocentral distances of the same events. Using the computed apparent velocity value, $t_{s}-$ $t_{p}$ intervals, a $V_{p} / V_{s}$ ratio of 1.73 , and the results of polarisation and particle-motion analyses, Sgroi et al. [2007] estimated the location of a dataset of 213 earthquakes recorded only by the SN1 (Figure 8). This seismicity is linked to the main tectonic structures that are active in the Ionian Sea area, namely the external Calabrian Arc accretionary prism associated with the subduction process, the tectonic structures related to the Malta Escarpment, and the seismogenic structures that are active in the deep Ionian Basin [Polonia et al., 2016a, 2017]. SN1 recorded many low magnitude earthquakes that were not recorded by land stations. This is certainly due to the low signal-to-noise ratio due to the volcanic tremor associated to some explosive phases that accompanied the 2002-2003 Mt. Etna eruption [Sgroi et al., 2007]. High amplitudes of volcanic tremor obscured low magnitude earthquakes on land seismograms. On the other hand, the same increase in the background noise due to the volcanic tremor was also visible on SN-1 seismograms, but it did not obscure the signal of interest [Sgroi et al., 2007; Sgroi et al., 2019].

During the SEISMOFAULTS experiment (from May 2017 to May 2018), about 140 earthquakes were located off eastern Sicily and southern Calabria (Ionian Sea) by the Italian Seismic Network (ISN) managed by the INGV. Presently, the ISN consists of about 90 broadband three-component stations (Trillium $40 \mathrm{~s}$ sensors) deployed in Sicily, the Aeolian Islands, and southern Calabria. This network can optimally locate earthquakes occurring on land, but the lack of adequate marine coverage prevents the accurate location of events occurring offshore. 
Using the data recorded by the marine seismometers (OBS/H) during the SEISMOFAULTS project, we expect to improve the location accuracy of earthquakes in the Ionian Sea by decreasing the azimuthal gap and decreasing the error of the hypocentral parameters. For instance, in Table 4, the location parameters are shown for eight events (sketched with blue circles in Figure 8 of this work) located with only land stations vs. the integrated locations with SN1 arrival times. Note that a decrease of $52^{\circ}$ in azimuthal GAP is obtained for the earthquake occurred on 2 October 2014 at 13:17pm. In Figure 9, we show all the waveforms from the SEISMOFAULTS marine seismometers (i.e. seven OBS/H) and the waveforms from several ISN land stations for the 11 April $2018 \mathrm{M}_{\mathrm{L}} 3.7$ earthquake, which was located offshore of southern Calabria by the ISN (Lat. 37.7313, Lon. 15.9405, depth $42.4 \mathrm{~km}$; http://cnt.rm.ingv.it/). In general, despite marine seismograms having more complex waveforms due to multiples coming from the water surface and sediment layers, various seismic phases are clearly detectable by applying an adequate digital filter on the data.

Thanks to the seismological data from the OBS/H deployed during the SEISMOFAULTS project, we can confidently identify and locate a 'new' low-magnitude seismicity not recorded by the ISN, thus contributing to the identification of new seismically active faults or fault segments in the Ionian domain.

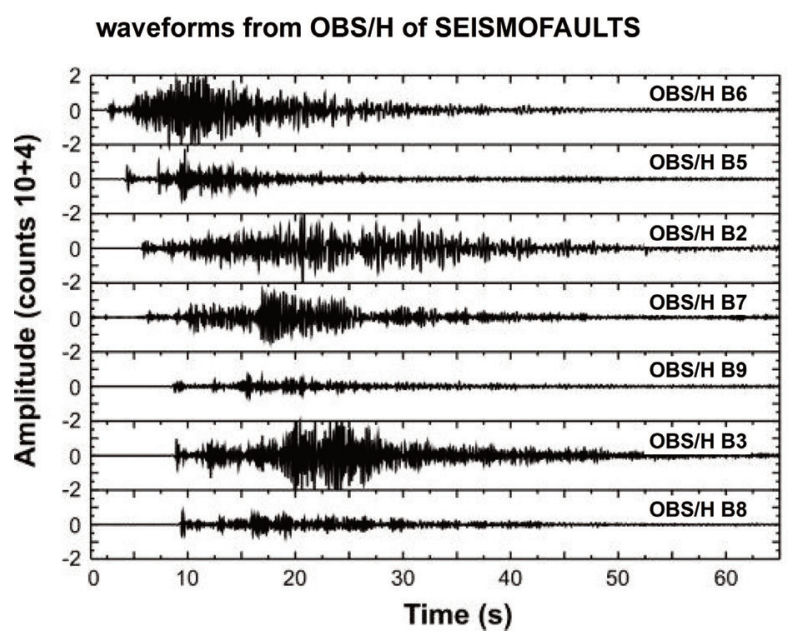

\section{waveforms from stations of Italian Seismic Network}

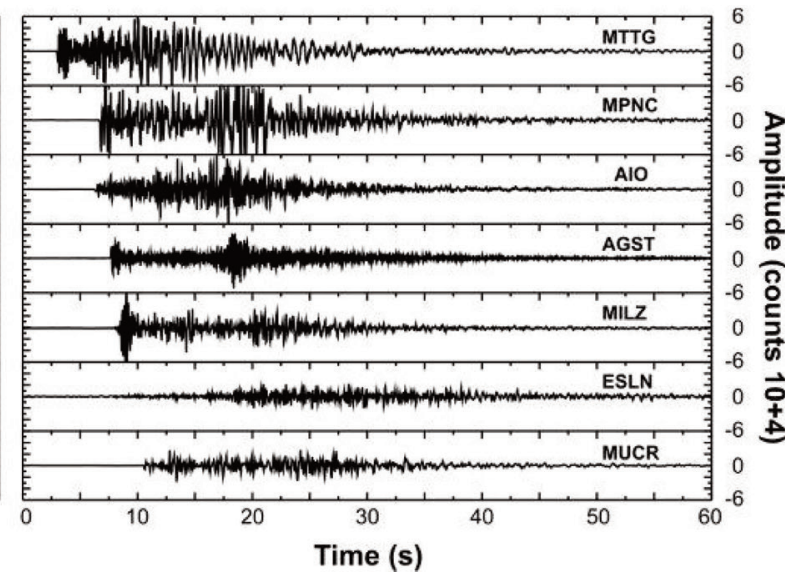

Figure 9. Seismic waveforms (vertical component) of the earthquake occurred off southern Calabria on 11 April, 2018 $\left(\mathrm{M}_{\mathrm{L}}=3.7\right)$. Waveforms are from the Seismofaults $2017 \mathrm{OBS} / \mathrm{H}$ compared with waveforms from some inland stations (see location of the MTTG, MPNC, AIO, AGST, MILZ, ESLN, and MUCR stations on https://www.fdsn.org/networks/detail/IV/). Waveforms from OBS/H are bandpass-filtered between 2-12 hz.

\subsection{Seawater column geochemical data}

The locations of the sites for the seawater column geochemical analyses are listed in Table 5 and given in WGS84 geographical coordinates.

\begin{tabular}{cccccccc} 
Name & depth $(\mathbf{m})$ & $\mathbf{H}_{2}$ ccSTP & $\mathbf{O}_{2}$ ccSTP & $\mathbf{N}_{2}$ ccSTP & CO ccSTP & $\mathbf{C H}_{4}$ ccSTP & $\mathbf{C O}_{2}$ ccSTP \\
\hline GEOC1 & 1043.50 & $6.33 \mathrm{E}-02$ & $3.91 \mathrm{E}+00$ & $9.55 \mathrm{E}+00$ & $2.65 \mathrm{E}-05$ & $1.37 \mathrm{E}-04$ & $7.71 \mathrm{E}-01$ \\
\hline GEOC1 & 1000 & $1.02 \mathrm{E}-01$ & $3.95 \mathrm{E}+00$ & $9.31 \mathrm{E}+00$ & $2.65 \mathrm{E}-05$ & $1.37 \mathrm{E}-04$ & $5.28 \mathrm{E}-01$ \\
\hline GEOC1 & 900 & $8.49 \mathrm{E}-02$ & $3.97 \mathrm{E}+00$ & $9.64 \mathrm{E}+00$ & $1.99 \mathrm{E}-05$ & $7.62 \mathrm{E}-05$ & $5.10 \mathrm{E}-01$ \\
\hline GEOC1 & 800 & $7.05 \mathrm{E}-02$ & $3.75 \mathrm{E}+00$ & $8.85 \mathrm{E}+00$ & $4.39 \mathrm{E}-05$ & $7.23 \mathrm{E}-05$ & $4.73 \mathrm{E}-01$ \\
\hline GEOC1 & 700 & $1.31 \mathrm{E}-01$ & $3.95 \mathrm{E}+00$ & $9.30 \mathrm{E}+00$ & $3.31 \mathrm{E}-05$ & $9.14 \mathrm{E}-05$ & $4.80 \mathrm{E}-01$ \\
\hline
\end{tabular}




\section{Andrea Billi et al.}

The chemical compositions of the water samples and the dissolved gases are listed in Tables 5 and 6.

\begin{tabular}{|c|c|c|c|c|c|c|c|}
\hline Name & depth (m) & $\mathrm{H}_{2} \mathrm{ccSTP}$ & $\mathrm{O}_{2} \operatorname{ccSTP}$ & $\mathbf{N}_{2} \mathbf{c c S T P}$ & CO ccSTP & $\mathrm{CH}_{4} \mathrm{ccSTP}$ & $\mathrm{CO}_{2} \mathrm{ccSTP}$ \\
\hline GEOC1 & 500 & $1.20 \mathrm{E}-01$ & $4.16 \mathrm{E}+00$ & $9.45 \mathrm{E}+00$ & $2.65 \mathrm{E}-05$ & $6.86 \mathrm{E}-05$ & $4.73 \mathrm{E}-01$ \\
\hline GEOC1 & 300 & $2.68 \mathrm{E}-02$ & $4.10 \mathrm{E}+00$ & $9.40 \mathrm{E}+00$ & $3.98 \mathrm{E}-05$ & 8.38E-05 & $4.95 \mathrm{E}-01$ \\
\hline GEOC1 & 200 & $1.63 \mathrm{E}-03$ & $4.58 \mathrm{E}+00$ & $9.73 E+00$ & $2.10 \mathrm{E}-05$ & $5.61 \mathrm{E}-05$ & $5.04 \mathrm{E}-01$ \\
\hline GEOC1 & 100 & $2.53 \mathrm{E}-03$ & $4.41 \mathrm{E}+00$ & $8.90 \mathrm{E}+00$ & $0.00 \mathrm{E}+00$ & $0.00 \mathrm{E}+00$ & $4.75 \mathrm{E}-01$ \\
\hline GEOC2 & 1648.75 & $0.00 \mathrm{E}+00$ & $3.93 E+00$ & $9.35 \mathrm{E}+00$ & $2.66 \mathrm{E}-05$ & $2.07 \mathrm{E}-04$ & $5.64 \mathrm{E}-01$ \\
\hline GEOC2 & 1500 & $1.04 \mathrm{E}-01$ & $4.23 \mathrm{E}+00$ & $8.98 E+00$ & $2.66 \mathrm{E}-05$ & $1.07 \mathrm{E}-04$ & $5.37 \mathrm{E}-01$ \\
\hline GEOC2 & 1300 & $5.26 \mathrm{E}-04$ & $3.77 \mathrm{E}+00$ & $8.98 \mathrm{E}+00$ & $1.89 \mathrm{E}-05$ & $1.24 \mathrm{E}-04$ & $4.62 \mathrm{E}-01$ \\
\hline GEOC2 & 1000 & $1.69 \mathrm{E}-02$ & $4.24 \mathrm{E}+00$ & $9.62 E+00$ & $0.00 \mathrm{E}+00$ & $2.30 \mathrm{E}-05$ & $4.56 \mathrm{E}-01$ \\
\hline GEOC2 & 700 & $1.99 \mathrm{E}-01$ & $4.04 \mathrm{E}+00$ & $9.99 \mathrm{E}+00$ & $1.26 \mathrm{E}-04$ & $1.77 \mathrm{E}-04$ & $4.67 \mathrm{E}-01$ \\
\hline GEOC2 & 600 & $3.22 \mathrm{E}-01$ & $3.94 \mathrm{E}+00$ & $9.21 \mathrm{E}+00$ & $0.00 \mathrm{E}+00$ & $6.90 \mathrm{E}-05$ & $4.39 \mathrm{E}-01$ \\
\hline GEOC2 & 500 & 7.72E-03 & $3.79 \mathrm{E}+00$ & $8.79 E+00$ & $0.00 \mathrm{E}+00$ & $5.82 \mathrm{E}-05$ & $4.50 \mathrm{E}-01$ \\
\hline GEOC2 & 300 & $1.10 \mathrm{E}-01$ & $4.24 \mathrm{E}+00$ & $9.48 \mathrm{E}+00$ & $0.00 \mathrm{E}+00$ & $7.67 \mathrm{E}-05$ & $4.67 \mathrm{E}-01$ \\
\hline GEOC2 & 100 & 8.74E-02 & $4.38 \mathrm{E}+00$ & $9.10 \mathrm{E}+00$ & 3.33E-05 & 1.07E-04 & $4.54 \mathrm{E}-01$ \\
\hline GEOC3 & 2029 & $0.00 \mathrm{E}+00$ & $3.98 \mathrm{E}+00$ & $9.20 \mathrm{E}+00$ & $0.00 \mathrm{E}+00$ & 5.33E-05 & $4.54 \mathrm{E}-01$ \\
\hline GEOC3 & 1500 & $2.13 \mathrm{E}-01$ & $3.51 \mathrm{E}+02$ & $9.85 \mathrm{E}+00$ & $0.00 \mathrm{E}+00$ & $1.90 \mathrm{E}-04$ & $4.97 \mathrm{E}-01$ \\
\hline GEOC3 & 1000 & $3.97 \mathrm{E}-02$ & $3.99 \mathrm{E}+00$ & $9.34 \mathrm{E}+00$ & $0.00 \mathrm{E}+00$ & $4.57 \mathrm{E}-05$ & $4.74 \mathrm{E}-01$ \\
\hline GEOC3 & 500 & $3.78 \mathrm{E}-02$ & $3.61 \mathrm{E}+00$ & $9.33 E+00$ & $2.51 \mathrm{E}-05$ & $2.02 \mathrm{E}-04$ & $4.90 \mathrm{E}-01$ \\
\hline GEOC3 & 100 & $7.56 \mathrm{E}-02$ & $4.54 \mathrm{E}+00$ & $9.30 \mathrm{E}+00$ & $5.30 \mathrm{E}-04$ & $9.14 \mathrm{E}-05$ & $4.68 \mathrm{E}-01$ \\
\hline ASSW & & $4.1 \mathrm{E}-5$ & 4.80 & 9.60 & & $1.0 \mathrm{E}-6$ & 0.24 \\
\hline
\end{tabular}

Table 5. Geochemical data from the analyses of the seawater columns.

\begin{tabular}{|c|c|c|c|c|c|c|c|c|c|}
\hline Sample & $\begin{array}{l}\text { Depth } \\
\text { (m) }\end{array}$ & Longitude & Latitude & $\mathbf{T}\left({ }^{\circ} \mathbf{C}\right)$ & pH & $\begin{array}{l}\text { Conductibility } \\
(\mathrm{mS} / \mathrm{cm})\end{array}$ & & & \\
\hline GEOC1 & 1043.50 & $15^{\circ} 28.50$ & $37^{\circ} 57.42^{\prime}$ & 13.8 & 8.16 & 46.2 & & & \\
\hline GEOC2 & 1648.75 & $15^{\circ} 26.68^{\prime}$ & $37^{\circ} 48.18^{\prime}$ & 13.79 & 8.37 & 46.44 & & & \\
\hline GEOC3 & 2029 & $15^{\circ} 23.03^{\prime}$ & $37^{\circ} 28.18^{\prime}$ & 13.82 & 8.10 & 46.63 & & & \\
\hline Sample & $\underset{\mathrm{meq} / 1}{\mathrm{Na}}$ & $\underset{\mathrm{meq} / \mathrm{l}}{\mathrm{K}}$ & $\underset{\mathrm{meq} / 1}{\mathrm{Mg}}$ & $\underset{\mathrm{meq} / 1}{\mathrm{Ca}}$ & $\underset{\text { meq/1 }}{\mathrm{Cl}}$ & $\underset{\mathrm{meq} / \mathrm{l}}{\mathrm{Br}}$ & $\underset{\mathrm{meq} / 1}{\mathrm{SO4}}$ & A. $\mathbf{T}$. & $\begin{array}{c}\text { B.C. } \\
\%\end{array}$ \\
\hline GEOC1 & 553 & 12.7 & 125 & 24.9 & 644 & 0.930 & 67.1 & 2.68 & 0.24 \\
\hline GEOC2 & 552 & 12.7 & 125 & 25.2 & 637 & 0.999 & 66.5 & 2.68 & 1.12 \\
\hline GEOC3 & 554 & 12.8 & 126 & 25.6 & 641 & 1.01 & 66.1 & 2.70 & 1.00 \\
\hline
\end{tabular}

Table 6. Geochemical-geophysical data from the analyses of the seawater columns. 
To enhance differences in geochemical composition of the samples from the three sites, analytical results are graphically presented in Figures 10(a) and 10(b). The sampled waters show a pH between 8.10 and 8.37 and conducibility between 46.2 and $46.6 \mathrm{mS} / \mathrm{cm}$. The chemical composition of the water samples is described in terms of major ion contents.

The results of the chemical analyses of the gas extracted from the sampled seawaters point to the existence of a dissolved gas phase that is different from the atmosphere. Figure 10(a) shows the contemporary presence of atmospheric components (represented by $\mathrm{O}_{2}$ and $\mathrm{N}_{2}$ ), as well as $\mathrm{CO}_{2}$ typically originating from an endogenic source. The analytical results are plotted on the $\mathrm{CO}_{2}-\mathrm{O}_{2}-\mathrm{N}_{2}$ triangular diagram (Figure 10a), where typical atmospheric components (oxygen and nitrogen) are plotted besides an endogenic gas $\left(\mathrm{CO}_{2}\right)$. The air-saturated seawater (ASSW) end-member is also shown.

All dissolved gases have an $\mathrm{O}_{2} / \mathrm{N}_{2}$ ratio slightly lower than that of ASSW due to a relative decrease in oxygen concentration. The increase in $\mathrm{CO}_{2}$ content is quite evident. Figure $10 \mathrm{~b}$ shows typical endogenic components $\left(\mathrm{CO}_{2}\right.$ and $\mathrm{CH}_{4}$ ) versus the atmospheric component (here represented by $\mathrm{O}_{2}$ ) and the injection of $\mathrm{CO}_{2}$ in several sites. The concentrations of dissolved $\mathrm{CO}_{2}$ and $\mathrm{CH}_{4}$ are higher than those of ASSW in contrast to a lower $\mathrm{O}_{2}$ concentration, suggesting a contribution of endogenic gases to the expected equilibrium with the atmospheric gases. Figure 10b shows the occurrence of the dissolution processes responsible for $\mathrm{CO}_{2}$ loss and the enhancement of the less soluble species, such as $\mathrm{CH}_{4}$.
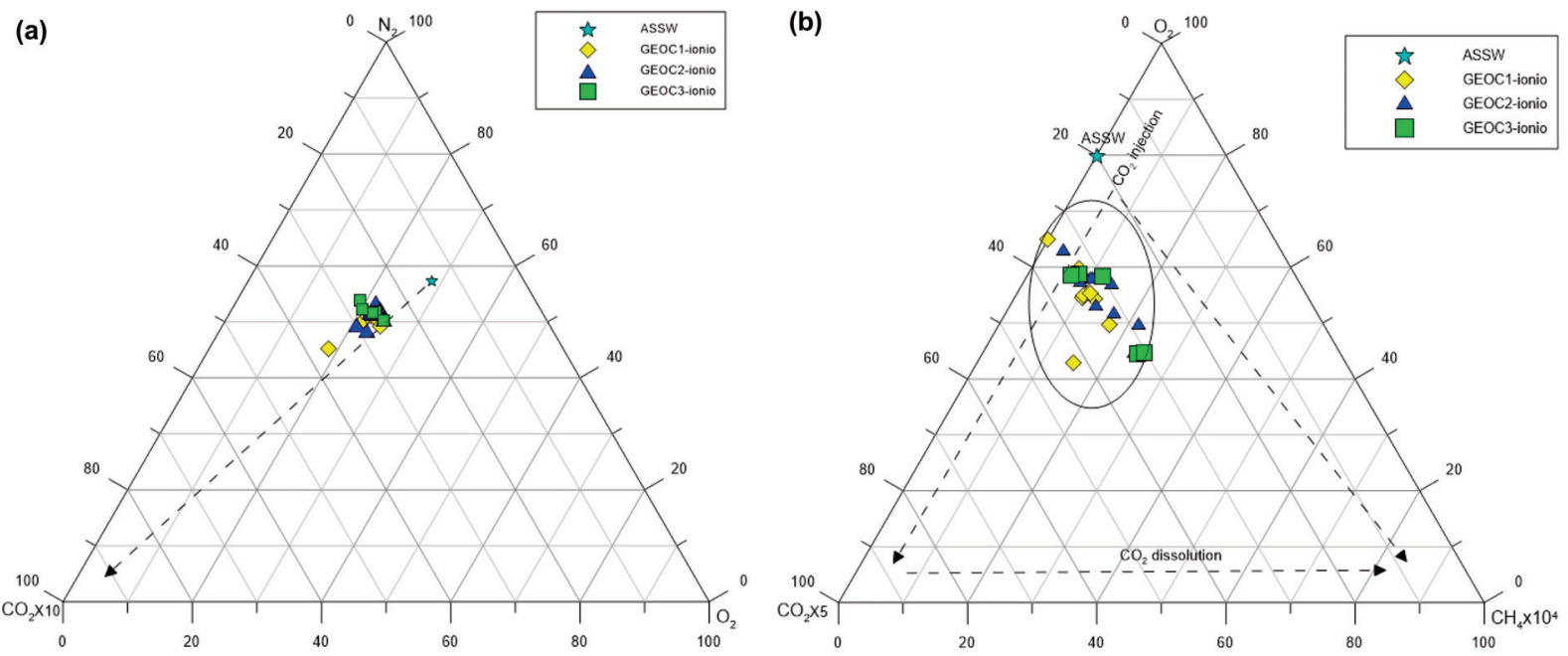

Figure 10. Ternary diagrams showing the composition of dissolved gases from three sampling sites (seawater column sampling at $\mathrm{GeoC} 1, \mathrm{GeoC2}$, and $\mathrm{GeoC} 3$ sites; Table 1) compared with the local air-saturated seawater (ASSW Tables 5 and 6). The concentrations of dissolved $\mathrm{CO}_{2}$ and $\mathrm{CH}_{4}$ are higher than those of ASSW in contrast to a lower $\mathrm{O}_{2}$ concentration, suggesting a contribution of endogenic gases to the expected equilibrium with the atmospheric gases. (a) The analytical results are plotted on the $\mathrm{CO}_{2}-\mathrm{O}_{2}-\mathrm{N}_{2}$ triangular diagram, where typical atmospheric components (oxygen and nitrogen) are plotted besides an endogenic gas $\left(\mathrm{CO}_{2}\right)$. The ASSW end-member (Air saturated Sea Water) is also shown. All dissolved gases have an $\mathrm{O}_{2} / \mathrm{N}_{2}$ ratio slightly lower than that of ASSW due to a relative decrease in oxygen concentration. The increase in $\mathrm{CO}_{2}$ content is quite evident. (b) This plot shows typical endogenic components $\left(\mathrm{CO}_{2}\right.$ and $\left.\mathrm{CH}_{4}\right)$ versus the atmospheric component (here represented by $\mathrm{O}_{2}$ ).

\section{Discussion and Conclusions}

The preliminary results from the Seismofaults 2017 and 2018 surveys in the Ionian Sea are useful for several reasons: 


\section{Andrea Billi et al.}

1. Recently, Polonia et al. [2011, 2012, 2016a, 2017] have drawn a series of long strike-slip to transtensional or transpressional faults cutting across the Calabrian accretionary wedge along the NW-SE direction (Figure 1); [see also Argnani and Bonazzi, 2005; Minelli and Faccenna, 2010; Gutscher et al., 2016, 2017; Dellong et al., 2018]. Moreover, the accretionary wedge is still active over thrust faults that dip towards the northwest and that developed in part over thick deposits of Messinian salt [Gutscher et al., 2006; Minelli and Faccenna, 2010; Polonia et al., 2011; Bortoluzzi et al., 2017]. As mentioned in the introductory section, the location, physical extension, and seismic potential of these faults is poorly constrained. The ensamble of OBS/H deployed in SEIMOFAULTS is a promising tool to detect local seismicity and identify unknown or hypothesized seimogenic structures in the western Ionian Sea as shown by previous experiments (Figs. 7-9). In particular, the many low magnitude earthquakes that are potentially missed by inland seismic stations can be recorded and precisely located by marine stations. Moreover, the location accuracy of all earthquakes (i.e. both those recorded solely by marine stations and those recorded by land and marine stations) can be greatly improved by the presence of a marine network of seismic stations. Data from seafloor instruments is necessary to obtain more realistic crustal velocity models. In turn, the velocity models are the base for the calculation of precise hypocentral locations of earthquakes [e.g., Dahm et al., 2002; Sgroi et al., 2006, 2007; Monna et al., 2013; Beranzoli et al., 2015]. Preliminary results indicate a good performance/response for identification of lowmedium magnitude earthquakes (Figure 9), thus from the data collected during the SEISMOFAULTS project, we expect to achieve a substantial improvement in earthquake location accuracy in the Ionian Sea area and therefore a substantial improvement in the knowledge of seismically active faults in this region.

2. Earthquake forecasting has been attempted using a wealth of different methods [e.g. Wyss, 1991]. Recent retrospective studies on geochemical anomalies as potential seismic precursors suggest that they can be a good candidate for earthquake forecasting [Inan et al., 2012]. To correctly understand the overall concept underpinning our attempt in the Ionian Sea, a few background studies must be considered: (a) In 1995, eight months before the M7.2 Kobe earthquake (Japan), the $\mathrm{Cl}$ and $\mathrm{SO}_{4}$ concentrations in groundwaters started to increase significantly and anomalously. Nine days before the earthquake, a peak in Rn concentration was recorded [Igarashi et al., 1995]. (b) In 2002, anomalies in the $\mathrm{Cu}, \mathrm{Zn}, \mathrm{Mn}$, and $\mathrm{Cr}$ concentrations in groundwaters were recorded one, two, five, and 10 weeks, respectively, before a M5.8 earthquake in northern Iceland [Claesson et al., 2004]. (c) In 2012, anomalous increases of $\mathrm{Ca}, \mathrm{Mg}, \mathrm{K}$, and $\mathrm{Cl}$ concentrations in groundwaters together with decreases of $\mathrm{Na}$ and $\mathrm{SO}_{4}$ concentrations started between 20 and 30 days before the M7.1 Van earthquake (Turkey) [Inan et al., 2012]. (d) In 2012, significant increases in the Na, Si, and Ca groundwater concentrations started four to six months before two $M \geqslant 5.5$ earthquakes in northern Iceland [Skelton et al., 2014]. (e) In 2016, concentrations of As, V, and Fe in groundwaters started to anomalously increase three to four months before the M6.0 Amatrice earthquake (Italy) [Barberio et al., 2017; Petitta et al., 2018; Boschetti et al., 2019; Barbieri et al., 2020]. The aforementioned works suggest that within the seismic cycle and during the preparatory phase for moderate-large earthquakes, the Earth's intermediate crust undergoes fracturing, and might allow deep fluids to ascend and contaminate shallow aquifers. The continuous geochemical and physical monitoring of groundwaters could therefore help scientists identify anomalies in temporal series that could potentially constitute reliable hydrogeochemical seismic precursors. For these reasons, we decided to use two multiparametric geochemical-geophysical observatories coupled with a dense network of OBS/H (Figure 2). Moreover, we searched and surveyed venting structures such as mud volcanoes (Figure 6). We expect that the two geochemical modules (i.e. located along potentially active faults) can record possible geochemical anomalies that are associated to the preparation phase of an earthquake or, more in general, to the seismic cycle of seismically-active faults. Our preliminary results on the geochemistry of the seawater column show seawater contamination by endogenous fluids (Figure 10) along faults in the Ionian Sea. Further studies are necessary to confirm how these observations might help in the detection of an earthquake preparation phase.

3. The geophysical-geochemical characterisation of a recently signalled mud volcano [Figure 6; Gutscher et al., 2017; Loher et al., 2018; Cuffaro et al., 2019], which will be further explored in future surveys, can help in the comprehension of fluid flow-related geological processes, in particular in active tectonic processes. Active mud volcanoes in the Ionian Sea and elsewhere could provide information on the seismic cycle of nearby faults [e.g. Bouleguè et al., 1985; Gorgoni et al., 1988; Martinelli et al., 1991, 1995; Gulijev and Feizullayen, 1997; Milkov, 2000; Dimitrov, 2002; Kopf, 2002, Mazzini and Etiope, 2017] and could therefore be important targets for future geochemical monitoring [Cuffaro et al., 2019], as mentioned above. 
4. The Sicilian and Calabrian margins of the Ionian Sea are very steep and dominated by gravitational instability phenomena including several submarine slides. The occurrence of strong earthquakes in this region, as well as its fast uplift and presence of a giant volcano (Mt. Etna) make gravitational slides a significant hazard source in the Ionian region. In particular, Billi et al. [2008, 2010] ascribed the occurrence of tsunamis that occurred after the 1908 earthquake and previous earthquakes, mostly to seismically triggered submarine slides [Schambach et al., 2020]. Seismic stations (both on land and in marine areas) are able to record, identify, and precisely locate (submarine) landslides [Kanamori and Given, 1982; Kawakatsu, 1995; Dreger et al., 1998; Ristau, 2008; Lin et al., 2010] as well as earthquakes. We therefore expect that data from the OBS/H devices deployed in the Ionian Sea will be useful for locating submarine mass movements and earthquakes and for identifying the possible temporal and spatial relationships between them.

5. The SEISMOFAULTS project is a significant test for the underwater devices used. The quality of the data is heavily dependent on several instrumental factors: (a) correct and reliable recording of all data; (b) duration of batteries that ensures full functionality, including data recording, clock use (for post-survey synchronisation), and release from ballast at the time of recovery; (c) complete impermeability and duration of materials; (d) resistance to water pressure (down to about $2800 \mathrm{~m}$ b.s.l. in the case of the Seismofaults 2017 campaign); (e) resistance to deep currents, and (f) resistance to fishing with trawl nets. All these aspects will be carefully evaluated and used to improve future scientific activities.

In conclusion, the SEISMOFAULTS project is a multidisciplinary geoscientific experiment, presently active in a densely populated region (Ionian Sea) that hosted some of the strongest earthquakes and tsunamis of the entire Mediterranean region along the Africa-Eurasia active plate boundary. Hence, this experiment should lead to a better understanding of seismogenic and tsunamogenic mechanisms, of which faults are seismically active, of which slope sectors are prone to gravity mass failure, and whether and where geochemical precursors of earthquakes can be identified and monitored. This experiment is engaging three main Italian scientific institutions for a total of about 35 scientists. It has so far required many technological facilities (scientific vessels, OBS/H, multiparametric observatories, and laboratories) and a connected large effort of management, coordination, and scientific planning to organize the marine campaigns and to coordinate all the scientists involved contemporaneously on the vessels and in the laboratories, as well as to organize the data management and processing. A first successful result of the experiment was the correct deployment of all marine devices and their safe recovery (except one OBS/H), the recovery of four gravity cores, the acquisition of $4970 \mathrm{~km}^{2}$ of high-resolution bathymetry, the sampling of sea waters along four sea water columns, and, last but not least, the integration of a a significant number of geoscientists with different scientific and technological expertise to reach a common objective. The large set of acquired data and those that will be soon processed and released might give impulse to a wide range of multidisciplinary studies. At present, the main goal is to advance the knowledge of seismogenic/tsunamogenic faults in the Ionian Sea and to build an experience that may constitute a model or a reference for future similar studies in other seas. We hope that this experiment is the first step of a long-term research program over the Italian and European seas, in areas that are prone to earthquakes and other potentially hazardous geological phenomena.

Data and Sharing Resources. All data used for this article are reported in the associated figures and tables or the related sources are properly cited within the article.

Acknowledgments. Captains M. Colorito and A. Castagna, the officers and the crew of the RN Minerva and R/N G. Dallaporta are thanked for their cooperation during the Seismofaults 2017 and 2018 surveys. B. Orecchio and two anonymous reviewers are warmly thanked for editorial handling and constructive comments.

\section{References}

Amodio-Morelli, L., G. Bonardi, V. Colonna, D. Dietrich, G. Giunta, F. Ippolito, V. Liguori, S. Lorenzoni, A. Paglionico, V. Perrone, G. Piccarreta, M. Russo, P. Scandone, E. Zanetti-Lorenzoni and A. Zuppetta (1976). L’Arco Calabro- 


\section{Andrea Billi et al.}

Peloritano nell'orogene appenninico-maghrebide, Mem. Soc. Geol. It., 17, 1-60.

Argnani, A. and C. Bonazzi (2005). Tectonics of eastern Sicily offshore, Tectonics, 24, TC4009, doi:10.1029/2004TC001656. Argnani, A., G. Brancolini, C. Bonazzi, M. Rovere, F. Accaino, F. Zgur and E. Lodolo (2009). The results of the Taormina 2006 seismic survey: possible implications for active tectonics in the Messina Straits, Tectonophysics, 476, 159-169.

Barberi, G., L. Beranzoli, P. Favali, G. Neri and T. Sgroi (2006). Seismic location improvements from an OBS/H temporary network in Southern Tyrrhenian Sea, Ann. Geophys., 49, 739-749.

Barberio, M.D., M. Barbieri, A. Billi, C. Doglioni and M. Petitta (2017). Hydrogeochemical changes before and during the 2016 Amatrice-Norcia seismic sequence (central Italy), Sci. Reports, 7, 11735, doi:10.1038/s41598-017-11990-8.

Barbieri, M., T. Boschetti, M.D. Barberio, A. Billi, P. Iacumin, E.M. Selmo, S. Franchini and M. Petitta (2020). Tracing deep fluid source contribution to groundwater in an active seismic area (central Italy): a combined geothermometric and isotopic (d13C) perspective. J. Hydrol., 582, 12449, doi:10.1016/j.jhydrol.2019.124495.

Barreca, G., M. Corradino, C. Monaco and F. Pepe (2018). Active Tectonics along the South East Offshore Margin of Mt. Etna: New Insights from High-Resolution Seismic Profiles, Geosciences, 8, 62, doi:10.3390/geosciences8020062.

Beranzoli, L., A. Ciafardini, G. Cianchini, M. De Caro, A. De Santis, P. Favali, F. Frugoni, G. Marinaro, S. Monna, C. Montuori, E. Qamili and T. Sgroi (2015). A first insight into the Marsili volcanic seamount (Tyrrhenian Sea, Italy): results from ORION-GEOSTAR3 experiment, in Seafloor Observatories: A New Vision of the Earth from the Abyss, P. Favali, L. Beranzoli and A. De Santis (Editors), Springer-Praxis Books in Geophysical Sciences, Chapter 24, Springer-Verlag Berlin Heidelberg, 623-641, doi:10.1007/978-3-642-11374-1.

Bianca, M., C. Monaco, L. Tortorici and L. Cernobori (1999). Quaternary normal faulting in south-eastern Sicily (Italy): a seismic source for the 1693 large earthquake, Geophys. J. Int., 139, 370-394.

Billi, A., R. Funiciello, L. Minelli, C. Faccenna, G. Neri, B. Orecchio and D. Presti (2008). On the cause of the 1908 Messina tsunami, Southern Italy, Geophys. Res. Lett., 35, L06301, doi:10.1029/2008GL033251.

Billi, A., L. Minelli, B. Orecchio and D Presti (2010). Constraints to the cause of three historical tsunamis (1908, 1783, and 1693) in the Messina Straits region, Sicily, southern Italy, Seismol. Res. Lett., 81, 907-915.

Bortoluzzi, G., A. Polonia, C. Faccenna, L. Torelli, A. Artoni, M. Carlini, S. Carone, G. Carrara, M. Cuffaro, F. Del Bianco, F. D’Oriano, V. Ferrante, L. Gasperini, R. Ivaldi, A. Laterra, M. Ligi, M. Locritani, F. Muccini, P. Mussoni, F. Priore, F. Riminucci, S. Romano and G. Stanghellini (2017). Styles and rates of deformation in the frontal accretionary wedge of the Calabrian Arc (Ionian Sea): controls exerted by the structure of the lower African plate, It. J. Geosci., 136, 347-364.

Boschetti, T., M. Barbieri, M.D. Barberio, A. Billi, S. Franchini and M. Petitta (2019). $\mathrm{CO}_{2}$ inflow and element desorption prior to a seismic sequence, Amatrice-Norcia 2016, Italy, Geochem. Geophys. Geosyst., 20, 2303-2317.

Bosman, A., D. Casalbore, M. Anzidei, F. Muccini, C. Carmisciano and F.L. Chiocci (2015). The first ultra-high resolution digital terrain model of the shallow-water sector around Lipari Island (Aeolian Islands, Italy), Ann. Geophys., 48, doi:10.4401/ag-6746.

Boulegué, J., X. LePichon and J.T. Liyama (1985). Prevision de tremblements de terre dans le region de Tokai, Japan, C.R. Acad. Sci., Paris, ser. 2, 301, 16, 1217-1219.

Buck, W.R., L.L. Lavier and A.N.B. Poliakov (2005). Modes of faulting at mid-ocean ridges, Nature, 434, 719-723.

Capasso, G. and S. Inguaggiato (1998). A simple method for the determination of dissolved gases in natural waters. An application to thermal waters from Vulcano Island. Appl. Geochem., 13, 631-642, doi:10.1016/S08832927(97)00109-1.

Casalbore, D., A. Bosman and F.L. Chiocci (2012). Study of recent small-scale landslides in geologically active marine areas through repeated multibeam surveys: examples from the southern Italy, in Submarine Mass Movement and Their Consequences, Y. Yamada, K. Kawamura, K. Ikehara, Y. Ogawa, R. Urgeles, D. Mosher, J. Chaytor and M. Strasser (Editors), Springer Netherlands, 573-582.

Ceramicola, S., D. Praeg, A. Cova, D. Accettella and M. Zecchin (2014). Seafloor distribution and last glacial to postglacial activity of mud volcanoes on the Calabrian accretionary prism, Ionian Sea, Geo-Mar. Lett., 34, 111-129, doi:10.1007/s00367-013-0354-y.

Cernobori, L., A. Hirn, J. H McBride, R. Nicolich, L. Petronio, M. Romanelli and Streamers/Profiles Working Groups (1996). Crustal image of the Ionian basin and its Calabrian margins, Tectonophysics, 264, 175-189.

Chamot-Rooke, N., C. Rangin, X. Le Pichon and Dotmed Working Group (2005). DOTMED: a synthesis of deep marine data in Eastern Mediterranean, Mém. Soc. géol. Fr., 177, 1-64. 
Coltelli, M., D. Cavallaro, G. D’Anna, A. D’Alessandro, F. Grassa, G. Mangano, D. Patanè and S. Gresta (2016). Exploring the submarine Graham Bank in the Sicily Channel, Ann. Geophys., 59, doi:10.4401/ag-6929.

Claesson, L., A. Skelton, C. Graham, C. Dietl, M. Mörth, P. Torssander and I. Kockum (2004). Hydrogeochemical changes before and after a major earthquake, Geology, 32, 641-644.

Cuffaro, M., A. Billi, S. Bigi, A. Bosman, C.G. Caruso, A. Conti, A. Corbo, A. Costanza, G. D’Anna, C. Doglioni, P. Esestime, G. Fertitta, L. Gasperini, F. Italiano, G. Lazzaro, M. Ligi, M. Longo, E. Martorelli, L. Petracchini, P. Petricca, A. Polonia and T. Sgroi (2019). The Bortoluzzi Mud Volcano (Ionian Sea, Italy) and its potential for tracking the seismic cycle of active faults, Solid Earth, 10, 741-763,

D’Alessandro, A., G. D’Anna, D. Luzio and G. Mangano (2009). The INGV's new OBS/H: analysis of the signals recorded at the Marsili submarine volcano, J. Volcanol. Geotherm. Res., 183, 17-29, doi:10.1016/j.jvolgeores.2009.02.008.

D’Alessandro, A., G. Mangano and G. D’Anna (2012). Evidence of persistent seismo-volcanic activity at Marsili seamount, Ann. Geophys., 55, doi:10.4401/ag-5515.

Dahm, T., M. Thorwart, R. Flueh, T. Braun, R. Herber, P. Favali, L. Beranzoli, G. D’Anna, F. Frugoni and G. Smriglio (2002). First deployment of new ocean bottom broadband seismological instruments in the Tyrrhenian Sea reveals unknown centers of submarine activity, EOS Trans. Am. Geophys. Un., 83 (29), 309-320.

Del Ben, A., C. Barnaba and A. Taboga (2008). Strike-slip systems as the main tectonic features in the Plio-Quaternary kinematics of the Calabrian Arc, Mar. Geophys. Res. 29, 1-12, doi:10.1007/s11001-007-9041-6.

Dellong, D., F. Klingelhoefer, H. Kopp, D. Graindorge, L. Margheriti, M. Moretti, S. Murphy and M.-A. Gutscher (2018). Crustal structure of the Ionian basin and eastern Sicily margin: Results from a wide-angle seismic survey, J. Geophys. Res., 123, 2090-2114, doi:10.1002/2017JB015312.

Dimitrov, L.I. (2002). Mud volcanoes-the most important pathway for degassing deeply buried sediments, Earth Sci. Rev., $59,49-76$.

Doglioni, C., S. Merlini and G. Cantarella (1999). Foredeep geometries at the front of the Apennines in the Ionian Sea (central Mediterranean), Earth Planet Sc. Lett., 168, 243-254, doi:10.1016/S0012-821X(99)00059-X.

Dreger, D., R. Uhrhammer, M. Pasyanos, J. Rranck and B. Romanowicz (1998). Regional and far-regional earthquake locations and source parameters using sparse broadband networks: A test on the Ridge crest sequence, Bull. Seismol. Soc. Am., 88, 1353-1362.

Favali, P. and L. Beranzoli (2006). Seafloor Observatory Science: a review, Ann. Geophys., 49, 515-567.

Favali, P., L. Beranzoli, G. D’Anna, F. Gasparoni, J. Marvaldi, G. Clauss, H. W. Gerber, M. Nicot, M.P. Marani, F. Gamberi, C. Millot and E. R. Flueh (2006). A fleet of multiparameter observatories for geophysical and environmental monitoring at seafloor, Ann. Geophys., 49, 659-680.

Favali, P., F. Chierici, G. Marinaro, G. Giovanetti, A. Azzarone, L. Beranzoli, A. De Santis, D. Embriaco, S. Monna, S., N. Lo Bue, T. Sgroi, G. Cianchini, L. Badiali, E. Qamili, M.G. De Caro, G. Falcone, C. Montuori, F. Frugoni, G. Riccobene, M. Sedita, G. Barbagallo, G. Cacopardo, C. Calì, R. Cocimano, R. Coniglione, M. Costa, A. D’Amico, F. Del Tevere, C. Distefano and F. Ferrera (2013). Nemo-sn1 abyssal cabled observatory in the western Ionian sea, IEEE J. Ocean. Eng., 38, 358-374, doi:10.1109/JOE.2012.2224536.

Favalli, M., E. Boschi, F. Mazzarini and M. T. Pareschi (2009). Seismic and landslide source of the 1908 Straits of Messina tsunami (Sicily, Italy), Geophys. Res. Lett., 36, L16304, doi:10.1029/2009GL039135.

Gallais, F., M.-A. Gutscher, D. Klaeschen and D. Graindorge (2012). Two-stage growth of the Calabrian accretionary wedge in the Ionian Sea (Central Mediterranean): constraints from depth-migrated multichannel seismic data, Mar. Geol., 326-328, 28-45, doi:10.1016/j.margeo.2012.08.006.

Gallais, F., D. Graindorge, M.-A. Gutscher and D. Klaeschen (2013). Propagation of a lithospheric tear fault (STEP) through the western boundary of the Calabrian accretionary wedge offshore eastern Sicily (Southern Italy), Tectonophysics, 602, 141-152., doi:10.1016/j.tecto.2012.12.026.

Giovanetti, G., S. Monna, N. Lo Bue, D. Embriaco, F. Frugoni, G. Marinaro, M. De Caro, T. Sgroi, C. Montuori, A. De Santis, G. Cianchini, L. Beranzoli and P. Favali (2016). Observing volcanoes from the seafloor in the Central Mediterranean Area, Remote Sens., 8, 298, doi:10.3390/rs8040298.

Gorgoni, C., O. Bonori, S. Lombardi, G. Martinelli and G.P. Sighinolfi (1988). Radon and Helium anomalies in mud volcanoes from Northern Apennines - a tool for earthquake prediction, Geochem. J., 22, 265-273.

Guidoboni, E., G. Ferrari, D. Mariotti, A. Comastri, G. Tarabusi, G. Sgattoni and G. Valensise (2018). CFTI5Med, Catalogo dei Forti Terremoti in Italia (461 a.C.-1997) e nell'area Mediterranea (760 a.C.-1500), Istituto Nazionale di Geofisica e Vulcanologia (INGV), http://storing.ingv.it/ctti/ctti5/ 


\section{Andrea Billi et al.}

Guliyiev, I.S. and A.A. Feizullayev (1997). All about mud volcanoes, Azerbaijan. Publ. House, Nafta Press, Baku.

Gutscher, M.-A., J. Roger, M.-A. Baptista, J.M. Miranda and S. Tinti (2006). Source of the 1693 Catania earthquake and tsunami (southern Italy): New evidence from tsunami modeling of a locked subduction fault plane, Geophys. Res. Lett., 33, L08309, doi:10.1029/2005GL025442.

Gutscher, M.-A., S. Dominguez, B. Mercier de Lepinay, L. Pinheiro, F. Gallais, N. Babonneau, A. Cattaneo A., Y. Le Faou, G. Barreca, A. Micallef and M. Rovere (2016). Tectonic expression of an active slab tear from high-resolution seismic and bathymetric data offshore Sicily (Ionian Sea), Tectonics, 35, 39-54, doi:10.1002/2015TC003898.

Gutscher, M.-A., H. Kopp, S. Krastel, G. Bohrmann, T. Garlan, S. Zaragosi, I. Klaucke, P. Wintersteller, B. Loubrieu, Y. Le Faou, L. San Pedro, S. Dominguez, M. Rovere, B. Mercier de Lepinay, C. Ranero and V. Sallares (2017). Active tectonics of the Calabrian subduction revealed by new multi-beam bathymetric data and high-resolution seismic profiles in the Ionian Sea (Central Mediterranean), Earth Planet. Sc. Lett., 461, 61-72.

Hirn, A., R. Nicolich, J. Gallart, M. Laigle, L. Cernobori and Group Etna Seis (1997). Roots of Etna volcano in faults of great earthquakes, Earth Planet. Sc. Lett., 148, 171-191.

Ibáñez, J. M., A. Díaz-Moreno, J. Prudencio, D. Patanè, L. Zuccarello, O. Cocina, B.-G. Lühr, F. Carrión, M. Coltelli, P.P. Bruno, F. Bianco, M. Hellweg, R. Abreu, G. Alguacil, I. Álvarez, C. Aranda, C. Benítez, L. Buontempo, M. Feriche, L. García, D. García-Quiroga, J.B. Martín, J. Morales, I. Serrano, M. Titos, L. Urbano, G. Aiesi, R. Azzaro, G. Barberi, M. Cantarero, P. Cappuccio, D. Cavallaro, D. Contrafatto, S. Di Prima, S. Falsaperla, M.F. Carlino, E. Giampiccolo, G. Larocca, C. Musumeci, M. Paratore, D. Pellegrino, M. Pulvirenti, S. Rapisarda, M. Sassano, L. Scarfi, L. Scuderi, A. Sicali, G. Tusa, T. Tuvè, E. Del Pezzo, S. Fiore, D. Galluzzo, M. La Rocca, M. Longobardi, L. Nocerino, S. Scognamiglio, C. Bottari, F. Criscuoli, P. De Gori, L. Giovani, A. Messina, M. Silvestri, S. Salimbeni, T. Dahm, A. García-Yeguas, A. Ontiveros, E. Coello, M. Cordero, C. Guillén, M.C. Romero, H. McCann, M. Bretón, S. Boyd, I. Koulakov and S. Abramenkov (2016a). TOMO-ETNA experiment at Etna volcano: activities on land, Ann. Geophys., 59, 4, S0427; doi:10.4401/ag-7080.

Ibáñez, J. M., J. Prudencio, A. Díaz-Moreno, D. Patanè, G. Puglisi, B.G. Lühr, F. Carrión, J.J. Dañobeitia, M. Coltelli, F. Bianco, E. Del Pezzo, T. Dahm, V. Willmott and V. Mazauric (2016b). The TOMO-ETNA experiment: an imaging active campaign at Mt. Etna volcano. Context, main objectives, working-plans and involved research projects, Ann. Geophys., 59, 4, S0426, doi:10.4401/ag-7079.

Igarashi, G., S. Saeki, N. Takahata, K. Sumikawa, S. Tasaka, Y. Sasaki, M. Takahashi and Y. Sano (1995). Groundwater Radon anomaly before the Kobe earthquake in Japan, Science, 269, 60-61, doi:10.1126/science.269.5220.60.

Inan, S., W. P. Balderer, F. Leuenberger-West, H. Yakan, A. Ozvan and F.T. Freund (2012). Springwater chemical anomalies prior to the $\mathrm{Mw}=7.2$ Van earthquake (Turkey), Geochem. J., 46, 11-16.

Kanamori, H. and J.W. Given (1982). Analysis of long-period seismic waves excited by the May 18, 1980, eruption of Mount St. Helens: A terrestrial monopole?, J. Geophys. Res., 87, 5422-5432, doi:10.1029//B087iB07p05422.

Kasahara, J., R. Iwase, T. Nakatsuka, Y. Nagaya, Y. Shirasaki, K. Kawaguchi and J. Kojima (2006). An experimental multidisciplinary observatory (VENUS) at the Ryukyu Trench using the Guam-Okinawa Geophysical Submarine Cable, Ann. Geophys., 49, 595-606.

Kawakatsu, H. (1995). Automated near-realtime CMT inversion, Geophys. Res. Lett., 22, 2569-2572, doi:10.1029/95GL02341.

Kopf, A.J. (2002). Significance of mud volcanism, Rev. Geophys., 40, 2, doi:10.1029/2000RG000093.

Lin, C. H., H. Kumagai, M. Ando and T.C. Shin (2010). Detection of landslides and submarine slumps using broadband seismic networks, Geophys. Res. Lett., 37, L22309, doi:10.1029/2010GL044685.

Loher, M., S. Ceramicola, P. Wintersteller, G. Meinecke, H. Sahling and G. Bohrmann (2018). Mud volcanism in a canyon: Morphodynamic evolution of the active Venere mud volcano and its interplay with Squillace Canyon, Central Mediterranean, Geochem. Geophys. Geosyst., 19, doi:10.1002/2017GC007166.

Martinelli, G., D. Albarello and M. Mucciarelli (1995). Radon emissions from mud volcanoes in Northern Italy: possible connection with local seismicity, Geophys. Res. Lett., 22, 15, 1989-1992.

Martinelli, G. and G. Ferrari (1991). Earthquake forerunners in a selected area of Northern Italy: recent developments in automatic geochemical monitoring, Tectonophysics, 93, 397-410.

Mazzini, A. and G. Etiope (2017). Mud volcanism: An updated review, Earth Sci. Rev., 168, 81-112.

Milkov, A.V. (2000). Worldwide distribution of submarine mud volcanoes and associated gas hydrates, Mar. Geol., 167, $29-42$.

Minelli, L. and C. Faccenna (2010). Evolution of the Calabrian accretionary wedge (Central Mediterranean), Tectonics, 
29, TC4004, doi:10.1029/2009TC002562.

Monaco, C. and L. Tortorici (2000). Active faulting in the Calabrian arc and eastern Sicily, J. Geodyn., 29, 407-424.

Monna, S., F. Frugoni, C. Montuori, L. Beranzoli and P. Favali (2005). High quality seismological recordings from the SN1 deep seafloor observatory in the Mt. Etna region, Geophys. Res. Lett., 32, L07303, doi:10.1029/2004GL021975.

Monna, S. and T. Dahm (2009). Three-dimensional P wave attenuation and velocity upper mantle tomography of the southern Apennines-Calabrian Arc subduction zone, J. Geophys. Res., 114, B06304, doi:10.1029/2008JB005677.

Monna, S., T. Sgroi and T. Dahm (2013). New insights on volcanic and tectonic structures of the southern Tyrrhenian (Italy) from marine and land seismic data, Geochem. Geophys. Geosyst., 14, doi:10.1002/ggge.20227.

Nicolich, R., M. Laigle, A. Hirn, L. Cernobori and J. Gallart (2000). Crustal structure of the Ionian margin of Sicily: Etna volcano in the frame of regional evolution, Tectonophysics, 329, 121-139, doi:10.1016/S0040-1951(00)00192-X.

Panieri, G., A. Polonia, R.G. Lucchi, S. Zironi, L. Capotondi, A. Negri and L. Torelli (2013). Mud volcanoes along the inner deformation front of the Calabrian Arc accretionary wedge (Ionian Sea), Mar. Geol., 336, 84-98, doi:10.1016/j.margeo.2012.11.003.

Petitta, M., L. Mastrorillo, E. Preziosi, F. Banzato, M.D. Barberio, A. Billi, C. Cambi, G. De Luca, P. Di Carlo, D. Di Curzio, C. Di Salvo, T. Nanni, S. Palpacelli, S. Rusi, M. Saroli, M. Tallini, A. Tazioli, D. Valigi, P. Vivalda and C. Doglioni (2018). Water-table and discharge changes associated with the 2016-2017 seismic sequence in central Italy: hydrogeological data and a conceptual model for fractured carbonate aquifers, Hydrogeol. J., 26, 1009-1026, doi:10.1007/s10040-017-1717-7.

Polonia, A., L. Torelli, P. Mussoni, L. Gasperini, A. Artoni and D. Klaeschen (2011). The Calabrian Arc subduction complex in the Ionian Sea: Regional architecture, active deformation, and seismic hazard, Tectonics, 30, TC5018, doi:10.1029/2010TC002821.

Polonia, A., L. Torelli, L. Gasperini and P. Mussoni (2012). Active faults and historical earthquakes in the Messina Straits area (Ionian Sea), Nat. Hazards Earth Syst. Sci., 12, 2311-2328, doi:10.5194/nhess-12-2311-2012.

Polonia, A., E. Bonatti, A. Camerlenghi, R.G. Lucchi, G. Panieri and L. Gasperini (2013). Mediterranean megaturbidite triggered by the AD 365 Crete earthquake and tsunami, Sci. Reports, 3, 1285, doi:10.1038/srep01285.

Polonia, A., L. Torelli, A. Artoni, M. Carlini, C. Faccenna, L. Ferranti, L. Gasperini, R. Govers, D. Klaeschen, C. Monaco, G. Neri, N. Nijholt, B. Orecchio and R. Wortel (2016a). The Ionian and Alfeo-Etna fault zones: new segments of an evolving plate boundary in the central Mediterranean Sea?, Tectonophysics, 675, 69-90, doi:10.1016/j.tecto.2016.03.016.

Polonia, A., S.C. Vaiani and G.J. De Lange. (2016b). Did the A.D. 365 Crete earthquake/tsunami trigger synchronous giant turbidity currents in the Mediterranean Sea?, Geology, 44, 191-194, doi:10.1130/G37486.1.

Polonia, A., H.C. Nelson, V. Romano, S.C. Vaiani, E. Colizza, G. Gasparotto and L. Gasperini (2017). A depositional model of seismo-turbidites in confined basins based on Ionian Sea deposits, Mar. Geol., 384, 177-198, doi:10.1016/j.margeo.2016.05.010.

Praeg, D., S. Ceramicola, R. Barbieri, V. Unnithan and N. Wardell (2009). Tectonically-driven mud volcanism since the late Pliocene on the Calabrian accretionary prism, central Mediterranean Sea, Mar. Petrol. Geol., 26, 1849-1865, doi:10.1016/j.marpetgeo.2009.03.008.

Presti, D., A. Billi, B. Orecchio, C. Totaro, C. Faccenna and G. Neri (2013). Earthquake focal mechanisms, seismogenic stress, and seismotectonics of the Calabrian Arc, Italy, Tectonophysics, 602, 153-175, doi:10.1016/j.tecto.2013.01.030.

Presti, D. (2020). Seismicity supports the theory of incipient rifting in the western Ionian sea, central Mediterranean. Ann Geophys., 63, doi:10.4401/ag-8360.

Ridente, D., E. Martorelli, A. Bosman and F.L. Chiocci (2014). High-resolution morpho-bathymetric imaging of the Messina Strait (Southern Italy). New insights on the 1908 earthquake and tsunami, Geomorphology, 208, $149-159$

Ristau, J. (2008). Implementation of routine regional moment tensor analysis in New Zealand, Seismol. Res. Lett., 79, 400 - 415, doi:10.1785/gssrl.79.3.400.

Rosenbaum, G., M. Gasparon, F.P. Lucente, A. Peccerillo and M.S. Miller (2008). Kinematics of slab tear faults during subduction segmentation and implications for Italian magmatism, Tectonics, 27, TC2008, doi:10.1029/2007TC002143.

Sano, Y., and H. Wakita (1988). Precise measurement of helium isotopes in terrestrial gases, Bull. Chem. Soc. Japan, 61, 1153-1157, doi:10.1246/bcsj.61.1153. 


\section{Andrea Billi et al.}

Scarfi, L., G. Barberi, C. Musumeci and D. Patanè (2016). Seismotectonics of northeastern Sicily and southern Calabria (Italy): New constraints on the tectonic structures featuring in a crucial sector for the central Mediterranean geodynamics, Tectonics, 35, 812-832.

Schambach, L., S.T. Grilli, D.R. Tappin, M.D. Gangemi and G. Barbaro (2020). New simulations and understanding of the 1908 Messina tsunami for a dual seismic and deep submarine mass failure source. Mar. Geol., 421, 106093, doi:10.1016/j.margeo.2019.106093.

Sgroi, T., T. Braun, T. Dahm and F. Frugoni (2006). An improved seismicity picture of the Southern Tyrrhenian area by the use of OBS and land-based network: the TYDE experiment, Ann. Geophys., 49, 801-817.

Sgroi, T., L. Beranzoli, G. Di Grazia, P. Favali and A. Ursino (2007). New observations of local seismicity by the SN-1 seafloor observatory in the Ionian Sea, off-shore Eastern Sicily (Italy), Geophys. J. Int., 169, 490-501, doi:10.1111/j.1365-246X.2007.03348.x.

Sgroi, T., C. Montuori, R. Agrusta and P. Favali (2009). Low-frequency seismic signals recorded by OBS at Stromboli volcano (Southern Tyrrhenian Sea), Geophys. Res. Lett., 36, L04305, doi:10.1029/2008GL036477.

Sgroi, T., S. Monna, D. Embriaco, G. Giovanetti, G. Marinaro and P. Favali (2014). Geohazards in the Western Ionian Sea: Insights from non-earthquake signals recorded by the NEMO-SN1 seafloor observatory, Oceanography, 27, 154166, doi:10.5670/oceanog.2014.51.

Sgroi, T., G. Di Grazia and P. Favali (2019). Volcanic tremor of Mt. Etna (Italy) recorded by NEMO-SN1 seafloor observatory: a new perspective on volcanic eruptions monitoring, Geosciences, 9, 115, doi:10.3390/geosciences9030115.

Skelton, A., M. Andrén, H. Kristmannsdóttir, G. Stockmann, C.M. Mörth, A. Sveinbjörnsdóttir, S. Jónsson, E. Sturkell, H.R. Guðrúnardóttir, H. Hjartarson, H. Siegmund and I. Kockum (2014). Changes in groundwater chemistry before two consecutive earthquakes in Iceland, Nat. Geosci., 7, 752-756.

Smith, D. K., J. Escartin, H. Schouten and J.R. Cann (2008). Fault rotation and core complex formation: Significant processes in seafloor formation at slow-spreading mid-ocean ridges (Mid-Atlantic Ridge, 13-15N), Geochem. Geophys. Geosyst., 9, Q03003, doi:10.1029/2007GC001699.

Sugisaki, R. and K. Taki (1987). Simplified analyses of He, Ne, and Ar dissolved in natural waters. Geochem. J., 21, 23-27, doi:10.2343/geochemj.21.23, 1987.

Tappin, D. R., Watts, P., Grilli, S. T., Dubosq, S., Billi, A., Pophet, N., and Marani, M. P. (2008). The 1908 Messina tsunami. Some comments on the source: Earthquake, submarine landslide or a combination of both?, Am. Geophys. Un., Fall Meeting 2008, abstract id. S41D-07.

Tinti, S., A. Maramai and L. Graziani (2004). The new catalogue of Italian Tsunamis, Nat. Hazards, 33, 439-465.

Totaro, C., D. Presti, A. Billi, A. Gervasi, B. Orecchio, I. Guerra and G. Neri (2013). The ongoing seismic sequence at Mt. Pollino Italy, Seismol. Res. Lett., 84, 955-962.

Trippetta, F., P. Petricca, A. Billi, C. Collettini, M. Cuffaro, A.M. Lombardi, D. Scrocca, G. Ventura, A. Morgante, and C. Doglioni (2019). From mapped faults to Fault-Length Earthquake Magnitude (FLEM): A test on Italy with methodological implications. Solid Earth, 10, 1555-1579, doi:10.5194/se-10-1555-2019.

Valensise, G. and D. Pantosti (1992). A 125 kyr long geological record of seismic source repeatability: the Messina Straits (southern Italy) and the 1980 earthquake (Ms 71/2), Terra Nova, 4, 472-483.

Wyss, M. 1991. Evaluation of proposed earthquake precursors, Am. Geophys. Un., Washington DC.

"CORRESPONDING AUTHOR: Andrea BILLI,

Consiglio Nazionale delle Ricerche, IGAG, c.o. Dipartimento di Scienze della Terra, Sapienza Università di Roma, Italy

e-mail: andrea.billi@cnr.it

() 2020 the Istituto Nazionale di Geofisica e Vulcanologia.

All rights reserved 